\title{
VEŘEJNÉ ZAKÁZKY V OBLASTI ICT A PROBLÉM ZÁVISLOSTI ZADAVATELE
}

\author{
JAN SVOBODA ${ }^{1}$
}

\begin{abstract}
ABSTRAKT
Častým jevem v ICT veřejných zakázkách je proprietární uzamčení veřejného zadavatele. Vypořádání se s tímto negativním jevem není snadné, protože nezř́dka představuje i nutnost vypořádání se s konfliktem jednotlivých účelů právní úpravy veřejných zakázek. Tento článek si klade za cíl poskytnout teoretická východiska pro snížení výskytu proprietárního uzamčení. Mimo jiné popisuje formy proprietárního uzamčení, jejich projevy, právní možnosti předcházení tomuto jevu a jeho řešení. Článek se rovněž věnuje migraci dat. Jsou $v$ něm navrženy $i$ dílčí změny současné právní úpravy.
\end{abstract}

\section{KLÍČOVÁ SLOVA}

Veřejná zakázka v oblasti ICT, proprietární uzamčení, veřejný zadavatel, dodavatel, podmínky kvalifikace, kritéria hodnocení, jednací ř́zení bez uveřejnění, migrace dat

\section{ABSTRACT}

Vendor lock-in is a frequent phenomenon at ICT public procurement. Dealing with this negative phenomenon is not easy because it often presents the necessity of dealing with the conflict of the individual purposes of public procurement regulation. This article aims to provide the theoretical basis for reducing the

\footnotetext{
1 Mgr. Jan Svoboda je doktorandem na Ústavu práva a technologií Právnické fakulty Masarykovy Univerzity v Brně. Vedle toho působí v mezinárodní advokátní kanceláři PricewaterhouseCoopers Legal. Kontaktní email: jan.svoboda@mail.muni.cz
} 
occurrence of the vendor lock-in. It describes, among other issues, forms of the vendor lock-in, their projections, legal possibilities to prevent this phenomenon and its subsequent solutions. The article also deals with data migration and proposes partial changes of the current legal regulation.

\section{KEYWORDS}

ICT public procurement, vendor lock-in, contracting authority, contractor, selection criteria, contract award criteria, negotiated procedure without prior publication, data migration

\section{1. ÚVOD}

Zadávání veřejných zakázek je upraveno zejména zákonem č. 134/2016 Sb., zákon o zadávání veřejných zakázek, ve znění pozdějších předpisů (dále jen „ZZVZ“). ${ }^{2}$ Základním účelem právní úpravy je zajištění hospodárného, efektivního a účelného vynakládání veřejných prostředků (princip 3E - economy, efectivness, efficiency). ${ }^{3}$ Zákon za tímto účelem vytváří podmínky pro uzavírání smluv mezi zadavatelem a dodavatelem veřejné zakázky při zajištění hospodářské soutěže a konkurenčního prostředí mezi dodavateli. ${ }^{4} \mathrm{~K}$ vytvoření těchto podmínek ZZVZ mimo jiné zakotvuje i zásady zadávání veřejných zakázek. Mezi tyto hlavní zásady patří zásada transparentnosti a přiměřenosti a zásada rovného zacházení a zákazu diskriminace vůči dodavatelům. ${ }^{5}$

Zatímco zajištění hospodářské soutěže je na úrovni národního práva primárně vnímáno jako prostředek pro dosažení principu 3E, na úrovni Evrop-

2 Článek v některých místech pracuje se zdroji, včetně správních rozhodnutí a judikatury, vztahujících se $\mathrm{k}$ již neúčinné právní úpravě (s ohledem na fakt, že např. ZZVZ nabyl účinnosti teprve v ř́inu roku 2016). $\mathrm{V}$ takových př́padech byly tyto zdroje vyhodnoceny jako relevantní a vhodné $\mathrm{i}$ ve vztahu $\mathrm{k}$ úpravě účinné $\mathrm{v}$ době př́ípravy článku.

3 Blíže k principu 3E viz např. HORKÝ, Michal. Možnosti efektivního zadávání veřejných zakázek z hlediska právní regulace v České republice [online]. Praha, 2017, s. 27-32 [cit. 21. 3. 2018]. Diplomová práce. Univerzita Karlova, Právnická fakulta. Vedoucí práce Radim BOHÁČ.

4 DVOŘÁK, David. Smluvní závazkové vztahy ve veřejných zakázkách [online]. Brno, 2013, s. 18 [cit. 19. 9. 2017]. Disertační práce. Masarykova univerzita, Právnická fakulta.

5 § ZZVZ. 
ské unie je důraz na hospodářskou soutěž mnohem vyšší, nebot' je zde hospodářská soutěž v odvětví veřejných zakázek chápána jako jeden z významných nástrojů rozvoje vnitřního trhu Evropské unie a způsobů předcházení nedovolené veřejné podpoře. ${ }^{6}$ Ve chvíli, kdy přiznáme hospodářské soutěži stejný význam jako principu 3E, tedy budeme oba aspekty chápat jako rovnocenné účely zadávání veřejných zakázek, můžeme se ocitnout (a často se ocitáme) v situaci, kdy naplnění jednoho účelu povede k rozporu s účelem druhým, jak bude dále přiblíženo.

Vzhledem $\mathrm{k}$ harmonizaci práva v oblasti zadávání veřejných zakázek na základě „zadávacích“ směrnic ${ }^{7}$ se dostává soutěžnímu prvku stále větší pozornosti. Proti tomuto přístupu se vymezuje např. Dvořák, když tvrdí, že je to právě účel zajištění hospodárného, efektivního a účelného vynakládání veřejných prostředků, kterému by při aplikaci práva veřejných zakázek měla být dána přednost. ${ }^{8}$

Střet těchto účelů může činit potíže při vypořádání se $s$ formami závislostí veřejných zadavatelů ${ }^{9}$ na svých dodavatelích a může zadavatele nutit nést významné náklady na změnu dodavatele. ${ }^{10}$ Někdy je také uváděn další účel procesu zadávání, a to uzavření kvalitního a vyváženého smluvního vztahu. $^{11,12}$

Častou formou závislosti zadavatele na dodavateli je proprietární uzamčení, neboli tzv. vendor lock-in (případně jen „uzamčení“ či „lockin“). Lock-in je stav negativně ovlivňující prostředí veřejného zadávání i hospodaření veřejných zadavatelů. Přes své negativní důsledky se stále

6 ŠIMKOVÁ, Dana. Přehled právní úpravy veřejného zadávání na úrovni EU a ve vybraných členských státech [online]. Praha, 2014, s. 4 [cit. 19. 9. 2017].

7 Mezi tyto směrnice patří ve vztahu k zadávání veřejných zakázek: i) směrnice Evropského parlamentu a Rady č. 2014/24/EU ze dne 26. 2. 2014 o zadávání veřejných zakázek a o zrušení směrnice 2004/18/ES, ii) směrnice Evropského parlamentu a Rady č. 2014/25/EU ze dne 26. 2. 2014 o zadávání zakázek subjekty působícími v odvětví vodního hospodářství, energetiky, dopravy a poštovních služeb a o zrušení směrnice č. 2004/17/ES a iii) směrnice Evropského parlamentu a Rady č. 2009/81/ES ze dne 13. 7. 2009 o koordinaci postupů při zadávání některých zakázek na stavební práce, dodávky a služby zadavateli v oblasti obrany a bezpečnosti a o změně směrnic č. 2004/17/ES a č. 2004/18/ES.

8 DVOŘÁK, 2013, op. cit., s. 19.

9 Není-li uvedeno jinak, mají označení „zadavatel“ a „veřejný zadavatel“ pro účely tohoto článku význam, jaký označení „veřejný zadavatel“ přikládá ZZVZ. 
jedná o častý jev, zvláště pak v ICT veřejných zakázkách. Dle průzkumu provedeného společností PricewaterhouseCoopers se $\mathrm{v}$ nějaké $\mathrm{z}$ forem ICT lock-inu ocitlo $42 \%$ dotázaných zadavatelů např́íc Evropskou unií. ${ }^{13}$

Tento článek si klade za cíl poskytnout teoretická východiska pro snížení výskytu proprietárního uzamčení, využitelná především veřejnými zadavateli.

K dosažení tohoto cíle je v článku vycházeno nejen z právně ale i ekonomicky a technicky zaměřených zdrojů. Pro maximální využitelnost článku je kladen důraz na používání teoretických př́íkladů i př́ikladů z praxe, aby popisované skutečnosti byly snadno představitelné.

V obecné části článku jsou v prvních třech kapitolách popsány významné formy proprietárního uzamčení a důvody jejich vzniku, specifika ICT veřejných zakázek ve vztahu $\mathrm{k}$ vendor lock-inu a přímé a nepřímě projevy uzamčení. Veřejní zadavatelé tak mohou hrozbu uzamčení, případně již vzniklý lock-in, na základě těchto kapitol odhalit.

$10 \mathrm{Z}$ rozhodovací praxe Úřadu pro ochranu osobních údajů je možné uvést např. rozhodnutí ze dne 11. 10. 2017, č. j. ÚOHS-S0309/2017/VZ-29605/2017/523/HVo, potvrzené rozhodnutím předsedy Úřadu pro ochranu hospodářské soutěže o rozkladu ze dne 2. 1. 2018, č. j. ÚOHS-R0192/2017/VZ-37799/2017/323/Lva. V tomto př́ipadě se dle Úřadu pro ochranu hospodářské soutěže veřejnému zadavateli nepodařilo prokázat splnění zákonných podmínek pro využití jednacího řízení bez uveřejnění (a tedy pro omezení hospodářské soutěže při zadávání navazující veřejné zakázky, přičemž by s největší pravděpodobností bylo dostáno principu 3E), ke kterému veřejný zadavatel přistoupil. Za toto jednání byla veřejnému zadavateli uložena pokuta ve výši 270000 Kč. V této věci pořídil veřejný zadavatel statutární město Brno veřejnou zakázku „Rozšiřrení a rozvoj systému GINIS“. Systém GINIS lze považovat za hromadný typový produkt a poskytnutí zdrojového kódu (předpoklad pro další rozvoj) tak není standardní obchodní praktikou. Otázkou tedy zůstává, zda by lock-in způsobený pořízením hromadného typového produktu a „nedostatečnou úpravou smluvních podmínek“ měl být Úřadem pro ochranu hospodářské soutěže považován za zaviněnou exkluzivitu, či nikoli. Blíže $\mathrm{k}$ zaviněné exkluzivitě, použití jednacího řízení bez uveřejnění a rozhodovací praxi Úřadu pro ochranu hospodářské soutěže viz kapitolu 5 Jednací ř́zení bez uveřejnění $v$ aplikační praxi.

11 DVOŘÁK, 2013, op. cit., s. 19.

12 Lze usuzovat, že uzavření vyváženého smluvního vztahu v oblasti veřejných zakázek není v praxi věnována pozornost. Ve skutečnosti se totiž jedná o adhezní smlouvy typu „take it, or leave it“. Jedná se o smlouvy sestavované zadavateli na ochranu jejich práv. Zajištovací a utvrzovací mechanismy jsou tedy v zásadě jednostranné. Smluvní vztah tak ve skutečnosti většinou logicky vyvážený není.

${ }^{13}$ Study on best practices for ICT procurement based on standards in order to promote efficiency and reduce lock-in [online]. 2015, s. 8 [cit. 1. 10. 2017]. 
Za účelem předejití lock-inu jsou ve čtvrté kapitole identifikovány nástroje, které při sestavování zadávací dokumentace umožňují snížit riziko uzamčení již před jeho vznikem a samotnou kontraktací s dodavatelem poptávaného plnění. Tato kapitola je tak zaměřena zejména na řádné definování předmětu veřejné zakázky a její podkapitoly také na možnosti koncepce podmínek kvalifikace a kritérií hodnocení.

Nepovede-li se proprietárnímu uzamčení předejít, je možné využít nástroje pro řešení vzniklé situace, které jsou stanoveny v ZZVZ, zvláště pak jednací řízení bez uveřejnění (dále jen „JŘBU“). Proto je právě popisu tohoto druhu zadávacího řízení a analýze podmínek pro jeho využití věnován zvláštní prostor $\mathrm{v}$ páté kapitole tohoto článku. Tento druh řízení, jak je v článku přiblíženo, lze považovat za proces s restriktivně vykládanými možnostmi využití. Právě zde se nejvíce projevuje problematika poměřování již zmíněného principu $3 \mathrm{E}$ a hospodářské soutěže. Vzhledem ke komplikovanosti toho, jak ke vzniklému lock-inu přistoupit, obsahuje tato část článku i přehled vybraných rozhodnutí dozorového úřadu, tedy Úřadu pro ochranu hospodářské soutěže, a judikatury zaobírající se danou problematikou.

Zvláště závažné může být uzamčení $\mathrm{v}$ případě nutnosti migrace dat. Z tohoto důvodu je v šesté kapitole pojednáno o smluvním zajištění takovéto migrace tak, aby k lock-inu nedošlo, i o možnostech mandatorní migrace dle zákonných institutů. Je třeba zdůraznit, že zákonné možnosti pro povinnou migraci dat směrem od dodavatele $\mathrm{k}$ veřejnému zadavateli byly do právního řádu, $\mathrm{v}$ reakci na problematiku lock-inu, zařazeny teprve $\mathrm{v}$ roce 2017. Jedná se tak o relativně novou možnost postupu veřejných zadavateli̊. Popsány jsou i aspekty migrace osobních údajů, zvláště ve spojení s Nařízením (EU) č. 2016/679 ze dne 27. 4. 2016 (dále jen „GDPR“).

V neposlední řadě je $\mathrm{v}$ článku diskutován problém uzamčení z důvodů vysokých nákladi̊ na změnu, tzv. „switching-costs“ lock-inu, a to ve zvláštní části tohoto článku, konkrétně v kapitole sedmé, nebot̉ se jedná o formu lock-inu bezprostředně odporující principu 3E. Právě náklady spojené s případnou změnou dodavatele totiž (významně) negativně ovlivňují rozpočet veřejného zadavatele. 
V př́padech, kdy jsou identifikovány nedostatky v účinné nebo chystané právní úpravě omezující efektivní řešení vendor lock-inu, jsou v článku navrhnuta i opatření $\mathrm{k}$ odstranění těchto nedostatků.

Řešení dalších problémů, jako např. problematiky poskytnutí zdrojového kódu veřejným zadavatelem konkurenčnímu dodavateli, by přesahovalo rámec tohoto článku.

\section{POPIS FOREM ZÁVISLOSTÍ ZADAVATELE NA DODAVATELI A DŮVODŮ JEJICH VZNIKU}

Uzamčení se vyskytuje $\mathrm{v}$ různých formách $\mathrm{v}$ závislosti na důvodech svého vzniku. Tyto důvody mohou být představovány monopolem dodavatele, omezením způsobeným existencí práv duševního vlastnictví na straně dodavatele, technologickou závislostí zadavatele na dodavateli, inkompatibilitou pořízeného a na něj navazujícího řešení, brzkým zavedením technologií - „early adopters lock-in“, uzamčením zadavatele ostatními uživateli, osobním uzamčením a - zvláště z pohledu ICT veřejných zakázek významnými - nepřiměřenými náklady na změnu. ${ }^{14,}{ }^{15}$ Všechny tyto formy mohou v zásadě působit jednotlivě, vedle sebe, př́padně se i prolínat či vzájemně splývat.

Monopol na trhu implikuje uzamčení ihned po vyvstání potřeby směřující k pořízení služby, dodávky nebo stavební práce formou veřejné zakázky. Vzhledem ke struktuře trhu totiž existuje pouze jediný dodavatel, který by byl dané plnění schopný poskytnout a hospodářská soutěž tak z podstaty této struktury proběhnout nemůže. Monopol můžeme pro účely kategorizace uzamčení dále dělit na ekonomický monopol a monopol technologický. Ekonomický monopol vzniká za situace, kdy je dodavatel jediným, kdo dané plnění na trhu nabízí/poskytuje. Technologický monopol naproti tomu vzniká za situace, kdy je dodavatel jediným, kdo je dané plnění schopen poskytnout, a to $\mathrm{z}$ důvodu zvláštních technologických znalostí

${ }^{14}$ SJOERDSTRA, Bianca. Dealing with Vendor Lock-in [online]. Enschede, 2016, s. 3-5 [cit. 19. 9. 2017].

15 Výběr této kategorizace byl zvolen s odkazem na užitou literaturu. Vzhledem ke koncepci článku nemá zvolená kategorizace ambici odrážet procentuální výskyt jednotlivých druhů uzamčení v České republice. 
nebo schopností, kterými ostatní dodavatelé nedisponují. ${ }^{16}$ Monopol a s ním spojené důsledky, včetně možného zneužití dominantního postavení na trhu, je mimo základního rámce pro zadávání veřejných zakázek daného ZZVZ upraven i v hlavě třetí zákona č. 143/2001 Sb., o ochraně hospodáŕské soutěže, ve znění pozdějších předpisů, který ve svém $§ 11$ zneužití dominantního postavení na újmu jiných soutěžitelů nebo spotřebitelů zakazuje. Monopol zároveň může vyplývat i z výhradních práv duševního vlastnictví svědčících dodavateli. ${ }^{17}$

Práva duševního vlastnictví mohou být dalším nástrojem umožňujícím vznik uzamčení již při vyvstání samotné potřeby vypsání veřejné zakázky. Na rozdíl od ostatních důvodů vzniku uzamčení, kde se zpravidla jedná o důvody technologické, případně ekonomické či smíšené, představují práva duševního vlastnictví důvod čistě právní. Dodavatel, kterému práva duševního vlastnictví v daném případě svědčí, tato práva totiž obecně nemusí poskytnout komukoli dalšímu a může tak omezit hospodářskou soutěž $\mathrm{v}$ samém počátku. ${ }^{18} \mathrm{I} \mathrm{v}$ případě, kdy byla zakázka zadávána $\mathrm{v}$ dostatečně soutěžním prostředí, se může stát, že toto prostředí bude postupem času výrazně zredukováno. Představme si situaci, kdy jeden dodavatel, vyvíjející určitý produkt (např. informační systém pro nemocnice), poskytne tu stejnou licenci několika dalším dodavatelům, a ti se následně stanou účastníky $\mathrm{v}$ daném zadávacím řízení. Je-li tento produkt poskytnut zadavateli např. na dobu dvou let, je velmi pravděpodobné, že zadavatel bude mít o obdobný produkt opětovně zájem. $\mathrm{V}$ daném případě však může uběhnout doba, na kterou byla licence původním účastníkům udělena, a tudíž je jediným potenciálním dodavatelem obdobného řešení jen jedna konkrétní oso-

SJOERDSTRA, op. cit. s. 3.

17 Srov. ANDERSON, Birgitte. 'Intellectual Property Right' Or 'Intellectual Monopoly Privilege': Which One Should Patent Analysts Focus On? [online]. 2003, s. 1-32 [cit. 19. 9. 2017].

18 Za př́klad uzamčení, kde zadavatel přistoupil k JŘBU z důvodu autorských práv a technických důvodů, lze uvést zakázku „Vývoj informačního systému VIOLA, 2012, 2013, 2014“. Veřejný zadavatel Česká republika - Ministerstvo financí zde však neunesl důkazní břemeno a neprokázal oprávněnost využití JŘBU. K tomu blíže rozhodnutí Úřadu pro ochranu hospodářské soutěže ze dne 29. 6. 2017, č. j. ÚOHS-S0186/2017/VZ19607/2017/553/MBu. Blíže k JŘBU a s ním souvisejícímu důkaznímu břemenu viz kapitolu 5 Jednací ř́zení bez uveřejnění v aplikační praxi. 
ba. Jedinou možností, jak zajistit hospodářskou soutěž, by tak bylo zadání veřejné zakázky na alternativní řešení, které by bylo schopné nabídnout více účastníků. Takovéto řešení by však s sebou neslo i další dopady, jako třeba výdaje představované náklady na změnu navazujících procesů a systémů nebo na přeškolení pracovníků. Dále lze očekávat dočasnou ztrátu produktivity a s největší pravděpodobností i vyšší cenu samotného soutěženého řešení ( $\mathrm{v}$ případě zmíněného informačního systému pro nemocnice také např. náklady na migraci dat).

Další formou lock-inu je technologická závislost, v angličtině často spojovaná s pojmem „path dependence“. Spočívá v problému zadavatele adaptovat se na novou technologii. ${ }^{19}$ Obecně platí, že čím déle je jedna technologie používána, tím obtížnější je tuto technologii vyměnit za jinou. Důvody jsou nejen personální, kdy jsou uživatelé této technologie jednoduše zvyklí na určitý způsob práce, ale i pozvolné vytváření ekosystému, pracovního prostředí, v němž se daná technologie může stát důležitou součástí pro jeho řádné a bezproblémové fungování. ${ }^{20}$ Toto může vést $\mathrm{k}$ neefektivitě zadavatele a v konečném důsledku i k neefektivnímu vynakládání veřjných prostředků. Za extrémní případ technologické závislosti by mohla být označena situace, kdy by se zadavatel rozhodl pro outsourcing způsobem, kdy by byly veškeré ICT potřeby plněny externím dodavatelem. V takovém případě je to totiž právě tento dodavatel, který disponuje všemi potřebnými znalostmi (na rozdíl od zadavatele) a technologiemi, na kom je zadavatel technologicky závislý. Takovýto dodavatel disponuje např. kompletním zdrojovým kódem, ale i know-how nutným pro jeho úpravu, nebot je jediným, kdo se vývoje zdrojového kódu účastnil. Čím více je vyvíjený produkt personalizován pro daného zadavatele, tím je vyšší i riziko vzniku technologické závislosti. Takovýto produkt je totiž jen těžko nahraditelný ostatními, nepersonalizovanými produkty, a právě jemu na míru

19 Srov. LIEBOWITZ, Stan; MARGOLIS, Stephen. Path Dependence, Lock-In, and History. Journal of Law, Economics and Organization [Online]. 1995, vol. 11, no. 1, s. 205-226. [cit. 1. 10. 2017].

20 SCHULTE, Benjamin Krischan. Staying the Consumption Course: Exploring the Individual Lockin Process in Service Relationships. Berlin: Springer Fachmedien Wiesbaden, 2015, s. 7-23. 
pak bývají uzpůsobena i další navazující technologická řešení zadavatele. ${ }^{21}$ V praxi se tak může stát, že zadavatel svým vlastním jednáním - definováním předmětu veřejné zakázky jako personalizovaného produktu - vytvoří podmínky pro své uzamčení, navíc za vynaložení prostředků z vlastního rozpočtu, a za cenu, která je pravděpodobně vyšší, než by byla cena nepersonalizovaného řešení.

Variantou technologické závislosti je i uzamčení způsobené inkompatibilitou. Takové uzamčení vznikne, když je pro zajištění funkčnosti produktu od jednoho dodavatele nutné pořídit i další výrobky stejného dodavatele. ${ }^{22}$ Př́kladem může být nákup notebooků. Životnost baterií notebooků je omezena, a proto může časem vyvstat potřeba koupit baterie nové. Je velice pravděpodobné, že $\mathrm{z}$ důvodů kompatibility bude možné tyto baterie pořídit pouze od toho dodavatele, který dodal dané notebooky (či od skupiny autorizovaných dodavatelů daného výrobce), a to i přesto, že by na trhu mohly být jiné, levnější, baterie, případně baterie s lepšími vlastnostmi, které by však společně s původními notebooky netvořily funkční celek. Inkompatibilitou je tak omezována hospodářská soutěž hlavně na poli souvisejících produktů a komponentů a vyvázání se z takového uzamčení s sebou opět přináší značné náklady na změnu.

Na obdobném principu může vzniknout i uzamčení způsobené brzkým zavedením technologií. Řešení tohoto uzamčení však může být ještě problematičtější. Při brzkém zavedení technologií zadavatel zvažuje riziko neúspěchu nové technologie a možnost jejího relativně rychlého překonání na straně jedné a fakt, že je technologie $\mathrm{v}$ danou chvíli pravděpodobně nejlepší na trhu, společně s politickým úspěchem, který může zavedení této novinky přinést, na straně druhé. ${ }^{23} \mathrm{~V}$ případě, že se technologie osvědčí, toto brzké

${ }^{21}$ SJOERDSTRA, op. cit., s. 4.

${ }^{22}$ Srov. USURO, Abel. Research in Information Systems. In: ATKINSON, John; CROWE; Malcom (eds.). Interdisciplinary Research: Diverse Approaches in Science, Technology, Health and Society. Chichester: John Wiley \& Sons Ltd, 2006, s. 87.

23 Srov. ASCHHOFF, Birgit; SOFKA, Wolfgang. Innovation on demand - Can public procurement drive market success of innovations? Research Policy. [Online]. 2009, vol. 8, issue 8, s. 1235-1247. [cit. 30. 11. 2017]. 
zavedení obecně nepovede $\mathrm{k}$ uzamčení. ${ }^{24}$ Pokud se však technologie neosvědčí, respektive bude překonána technologií jinou, bude se postupem času stávat náročnější a nákladnější technologii udržovat a rozvíjet, což $\mathrm{v}$ konečném důsledku může vést ke stagnaci a uzamčení v jednom konkrétním bodě nebo k nutnosti kompletní výměny technologie provázané značnými náklady na změnu. ${ }^{25} \mathrm{Z}$ tohoto druhu uzamčení tak často nemusí těžit ani původní dodavatel, nebot’ i ten se v takové situaci často uchýlí k produkci jiných technologií. ${ }^{26}$

Další formou závislosti je tzv. osobní uzamčení. To vzniká z důvodu subjektivních preferencí objednatele a následně se typicky přeměňuje v závislost technologickou, nebot’ je na základě těchto preferencí stále více a více prohlubována technologická provázanost s jedním konkrétním řešením. K osobnímu uzamčení by v oblasti veřejných zakázek nemělo docházet za žádných okolností, nebot by se jednalo o přímý nesoulad s principem $3 \mathrm{E}$ i rozpor se základními zásadami pro zadávání veřejných zakázek.

Z hlediska vzniku je velmi zajímavou formou lock-inu uzamčení ostatními uživateli („network lock-in“). Tato forma je zajímavá zejména proto, že

${ }^{24}$ I proto podporuje Evropská unie inovativní zadávání veřejných zakázek - zejména metodou PCP (,pre-commercial procurement“), zvláště v oblasti aplikovaného výzkumu a vývoje. Sledována je především podpora vzniku nových technických řešení, na trhu prozatím nedostupných a postrádaných. K tomu viz webovou stránku: Pre-Commercial Procurement [online]. European Commission [cit. 26. 3. 2018].

25 V minulosti se mohli v uzamčení způsobeným brzkým zavedením technologií ocitnout např. ti, kdo v 80. letech 20. století zvolili technologii Betamax před VHS nebo ti, kdo okolo roku 2010 pořídili počítače s operačním systémem Solaris, jehož vývoj byl ukončen společností Sun Microsystems. Obdobnému problému pak čelili ti, kteří okolo roku 2011 pořídili mobilní telefony soperačním systémem MeeGo. Vývoj tohoto systému byl společností Nokia rovněž ukončen. Byt̉ jsou zmíněné operační systémy open source, podpora jejich vývoje ze strany zmíněných společností byla pro jejich rozvoj a konkurenceschopnost zásadní.

${ }^{26}$ Za ukázkový případ předejití tomuto druhu uzamčení lze považovat postup Newyorské policie. Ta začátkem roku 2018 začala s výměnou 36000 telefonů používajících operační systém Windows Phone. Vývoj tohoto systému byl společností Microsoft ukončen a telefony pořízené jen před dvěma lety přestaly být pro policii dostačující. Dobře nastavené smluvní podmínky s dodavatelem AT\&T však umožňují výměnu těchto telefonů za telefony společnosti Apple bez dalších zvláštních poplatků ze strany Newyorské policie. Dle smlouvy se totiž jedná o předpokládaný upgrade mobilních telefonů. K tomu viz MOON, Mariella. NYPD starts replacing cops' Windows Phones with iPhones. Engadget.cz [online]. Oath Tech Network Aol Tech., publikováno 6. 2. 2018 [cit. 6. 2. 2018]. 
je k ní zadavatel donucen ostatními uživateli, nikoli dodavatelem či neuváženým nastavením zadávacího řízení. ${ }^{27}$ Uzamčení vychází ze situace, kdy je některé řešení tak „zažité“ ostatními uživateli, že odmítají řešení jiné, byt by pro zadavatele mohlo být výhodnější. Vzhledem $\mathrm{k}$ tomu, že zadavatel technické řešení často nevyužívá pouze pro své interní potřeby, ale i pro komunikaci s dalšími osobami nebo pro prezentaci svých výstupů, musí brát ohled i na další uživatele. ${ }^{28}$ Typickým př́́kladem uzamčení ostatními uživateli může být využívání některého formátu pro elektronické dokumenty. Pokud zadavatel dospěje k názoru, že je pro něj výhodnější (např. z finančních nebo uživatelských důvodů) využívat software používající výhradně jiný, nepřevoditelný, či obtížně převoditelný, formát, pak toto řešení pravděpodobně nezvolí právě z důvodu, že by jej museli zvolit i ostatní uživatelé. Dalším příkladem může být použití méně běžných komunikačních kanálů (chatovacích programů). QWERTY standard pro klávesnice je v současné době rovněž uzamčením způsobeným dalšími uživateli. ${ }^{29}$ Přesto, že toto rozložení kláves není pro všechny jazyky tím nejvýhodnějším, uživatelé jsou na něj zvyklí. Dodavatelé tedy z důvodu vyhovění všeobecné poptávce vyrábějí právě tyto klávesnice, př́ípadně jejich nepatrné modifikace, a zadavatelovy možnosti zakoupit jiné řešení jsou značně omezené. $\mathrm{V}$ posledním uvedeném př́kladu však není redukována soutěž ve smyslu počtu soutěžitelů, nýbrž ve smyslu počtu substitutů.

Vhledem k cíli zajištění hospodárného, efektivního a účelného vynakládání veřejných prostředků je to právě uzamčení z důvodu nákladu na změnu, kterému bude věnována speciální pozornost ve zvláštní kapitole tohoto článku. ${ }^{30}$ Problém uzamčení náklady na změnu pramení z před-

\footnotetext{
Srov. FARRELL, Joseph; KLEMPERER, Paul. Coordination and lock-in: competition with swithing costs and network effect. In: ARMSTRONG, M.; PORTER, R. (eds.). Handbook of Industrial Organization. [Online]. 2007, vol. 3, s. 1974-1996 [cit. 30. 11. 2017].

28 Srov. LIEBOWITZ, Stan; MARGOLIS, Stephen: Network Externality: An Uncommon Tragedy. The New Palgrave's Dictionary of Economics and the Law [online]. 1998, vol. 8, no. 2, s. 133-150 [cit. 30. 11. 2017].

29 CASTELLI, Annalisa. Technological lock-in and the shaping of enviromental policy. In: CASTELLUCCI, Laura (ed.). Government and the Environment: The Role of the Modern State in the Face of Global Challenges. London and New York: Routlege, 2014, s. 134.

30 Jedná se o kapitolu 7 Vendor lock-in z důvodu vysokých nákladů na změnu.
} 
pokladu, že přechod na jiné řešení možný je, stejně jako zajištění hospodářské soutěže, avšak za nutnosti vynaložení nákladů, které nekorespondují $\mathrm{s}$ užitkem přineseným touto změnou, respektive se zvoleným postupem. Tyto náklady na změnu pak mohou být často rovněž vyšší než hrozící poku$\mathrm{ta}^{31}$ za správní delikt udělená Úřadem pro ochranu hospodářské soutěže. ${ }^{32}$

\section{SPECIFIKA ICT VEŘEJNÝCH ZAKÁZEK VE VZTAHU K VENDOR}

\section{LOCK-INU}

Proprietární uzamčení se projevuje zvláště v ICT veřejných zakázkách. Důvodem je právě specifičnost sektoru informačních a komunikačních technologií. Oblast ICT je jednou z nejrychleji se rozvíjejících oblastí současného světa. ${ }^{33}$ Nové technologie jsou vyvíjeny každý den a jejich zavádění institucemi hospodařícími s veřejnými prostředky je nevyhnutelné. Tato nevyhnutelnost může být způsobena několika různými důvody. Vyjdeme-li z předpokladu, že technologie obecně usnadňují život, je to právě stát a jeho in-

${ }^{31}$ V roce 2014 se výši pokut za správní delikty ve veřejných zakázkách věnoval ve svém ekonometrickém modelu Martin Schmidt: SCHMIDT, Martin. Pokuty za správní delikty ve veřejných zakázkách: ekonometrický model. Acta Oeconomica Pragensia [online]. 2014, vol. 6, s. 35-50 [cit. 30. 11. 2017].

32 Lze odhadovat, že takovým př́padem je např. veřejná zakázka „Technická podpora a zajištění rozvoje aplikace NS-SIS II v letech 2016 - 2018“ zadaná veřejným zadavatelem Česká republika - Ministerstvo vnitra. $\mathrm{V}$ daném případě se veřejnému zadavateli nepodařilo prokázat splnění zákonných podmínek pro využití JŘBU, ke kterému přistoupil. Za toto mu Úřad pro ochranu hospodářské soutěže svým rozhodnutím ze dne 30. 8. 2017, č. j. ÚOHSS0277/2017/VZ-25377/2017/532/KSt uložil pokutu 1000000 Kč. Konečná hodnota této zakázky byla (dle Oznámení o zadání zakázky ve Věstníku veřejných zakázek uveřejněném dne 2. 3. 2016 pod ev. č. zakázky 516680) 165289256 Kč. Je tak velice pravděpodobné, že zadání veřejné zakázky na nové řešení vč. technické podpory a rozvoje aplikace by značně převyšovalo součet ceny pořízeného plnění a pokuty uložené Úřadem pro ochranu hospodářské soutěže, nebot by pořizované řešení zahrnovalo podstatně vyšší spektrum činností, přičemž tou zásadní by bylo právě dodání/vyvíjení nové aplikace.

33 „Výrazný náruist použivání informačních technologií $v$ současném světě vede na jedné straně $k$ vytvoření informační společnosti, urychlení komunikace a velkému rozvoji služeb a tím celé společnosti. Závislost společnosti a jejîho fungování na informačních technologiích rapidně narůstá, a to ve všech oblastech (nejedná se pouze o služby informační společnosti jako je internetový obchod, ale i o fungování informačních systémů, na jejichž správné funkci je závislá celá řada základních služeb jako např́klad ř́zení dopravy, přenos energií, výkon veřejné moci apod.). "Cit. z: Důvodová zpráva k zákonu č. 181/2014 Sb. o kybernetické bezpečnosti a o změně souvisejících zákonů. In: Beck-online [online právní informační systém]. Nakladatelství C. H. Beck [cit. 22. 3. 2018]. 
stituce, kdo by měl svým občanům usnadnit život zavedením technologií. K pořizování těchto technologií jsou pak využívány právě veřejné zakázky.

Dalším důvodem je efektivita těchto institucí, ke které by jim zavedení aktuálních technologií mělo pomoci, a v neposlední řadě pak i bezpečnost, která je informačními a komunikačními technologiemi zajištována. Napříč veřejnou správou dochází ke zpracování velkého množství dat, včetně osobních údajů, a jejich zpracování online, k čemuž je nutné zapojení informačních technologií. Vzhledem k nutnosti rychlého zavádění těchto technologií, jež daná situace nezřídka vyžaduje, ${ }^{34}$ často není možné předvídat důsledky pořízení dané technologie, nebot je těžké odhadnout nejen budoucí vývoj na trhu, ale i důkladně zmapovat současný stav daného prostředí.

Technologie jsou mnohdy pořizovány s výhledem na několik let. ${ }^{35} \mathrm{Je}-\mathrm{li}$ následně třeba vypsat zadávací řízení na nového provozovatele technologického řešení nebo na dodavatele služby spočívající v úpravě/rozvoji tohoto řešení, setkáváme se často $s$ faktem, že hospodářská soutěž ze své podstaty není možná (či je omezená), a to bud' z důvodů práv duševního vlastnictví znemožňujících jiným dodavatelům takové řešení nabídnout, nebo z technických a znalostních důvodů. Pro kvalitní nastavení zadávacího řízení a zadávání veřejných zakázek v oblasti ICT tak nestačí jen dostatečné právní znalosti, ale jsou nutné i znalosti z oblasti ICT a ekonomie.

ICT sektor je dále charakteristický vysokou mírou komplexity, specifičností jednotlivých řešení, často se vyskytující nutností intenzivní implementace a potřeby opakovaného/trvajícího dodávání zboží a poskytování služeb. ${ }^{36}$ Jsou to navíc právě dodavatelé, kterým uzamčení svědčí, a kteří zároveň často jako jediní disponují potřebnými znalostmi o fungování svých systémů a řešení, čímž mohou uzamčení vytvářet. Nevýhody uzamčení mohou být pro zadavatele představovány např. uživatelskou nepřívětivostí řešení, nedostatečným zabezpečením, nevyhověním nové právní úpravě a vysokými náklady na provoz. Zadavatelé se v uzamčení

\footnotetext{
34 Veřejní zadavatelé zpracovávající osobní údaje např. museli v relativně krátké době zavést opatření nutná k ochraně osobních údajů v souvislosti s použitelností GDPR.

35 SJOERDSTRA, op. cit., s. 2.

36 SJOERDSTRA, op. cit., s. 2.
} 
ocitnou, když jsou při výběru produktu „svázáni“ na základě svého předešlého nákupu souvisejícího produktu. ${ }^{37}$

ICT veřejné zakázky jsou rovněž specifické tím, že jejich výsledek často není pro veřejnost tak očividný jako výsledek jiných veřejných zakázek, např. stavebních prací. Kontrola veřejností tak v tomto případě může být snížena, což se projevuje zvláště u softwaru, jenž je charakteristický nehmatatelností výstupu.

V minulosti byly identifikovány rigidní vztahy v oblasti ICT, tedy vztahy $s$ vysokou mírou pravděpodobnosti vendor lock-inu, např. mezi těmito entitami: i) Ředitelství silnic a dálnic ČR a Kapsch Telematic Services spol. s r.o.; ii) Česká pošta, s.p. a Telefonica Czech Republic, a.s.; iii) VZP ČR a HEWLETT-PACKARD s.r.o. nebo iv) Česká správa sociálního zabezpečení a IBM Česká republika, spol. s r.o. ${ }^{38}$

\section{PŘÍMÉ A NEPŘÍMÉ PROJEVY VENDOR LOCK-INU}

Aby mohli veřejní zadavatelé lock-inu předcházet, případně jej řešit a pokusit se předejít jeho negativním důsledkům, nebo tyto důsledky alespoň zmírnit, je třeba vendor lock-in identifikovat. Vendor lock-in je možné identifkovat díky jeho přímým a nepřímým projevům.

Mezi přímé projevy lock-in efektu můžeme zařadit dlouhodobý vztah mezi zadavatelem a dodavatelem, využívání JŘBU a vyšší ziskovost daného dodavatele. ${ }^{39}$ Toto jsou projevy pozorovatelné jak účastníky vztahu - dodavatelem a zvláště zadavatelem, tak i „zvenčí“ tohoto vztahu.

Každý jednotlivý druh lock-inu má dále své vlastní, specifické, přímé projevy pozorovatelné př̌edevším jeho účastníky, přičemž v každém případě je projevem omezení hospodářské soutěže. Tyto přímé projevy zároveň často představují i charakteristické znaky uzamčení, jež byly prezentovány

${ }^{37}$ SHAH, Rajiv; KESAN, Jay; KENNIS, Andrew. Lessons for Open Standard Policies: A Case Study of the Massachusetts Experience. International Conference on Theory and Practice of Electronic Governance, Illinois Public Law Research Paper No. 0713. [online] University of Illinois, 2007, s. 7, [cit. 1. 10. 2017].

38 SKUHROVEC, Jiří. Vendor lock-in ve veřejných zakázkách [online]. Publikováno 16. 6. 2013, s. 14-15 [cit. 19. 9. 2017].

39 SKUHROVEC, op. cit., s. 11. 
v kapitole 1 Popis forem závislostí zadavatele na dodavateli a důvodů jejich $v z n i k u$. Konkrétně je důležité vyzdvihnout a připomenout, že uzamčení $\mathrm{z}$ důvodu monopolu se projevuje nemožností volby jiného dodavatele proto, že na relevantním trhu působí pouze jeden dodavatel schopný požadované plnění zajistit. V případě uzamčení způsobeným právy duševního vlastnictví je projevem možnost využití jednoho jediného dodavatele, která je zapříčiněna jeho právy $\mathrm{k}$ danému plnění. Technologická závislost a inkompatibilita se pak zpravidla projevují nemožností zvolit jiné technologické řešení, nebot jiné řešení by s původními součástmi netvořilo funkční celek. V oblasti migrace dat se technologická závislost projevuje kupř́íkladu nemožností přímého přenosu dat k novému dodavateli (poskytovali služby). Důvodem může být speciální kódování znemožňující využití dat mimo infrastrukturu dodavatele, případně také nemožnost data $\mathrm{z}$ této infrastruktury přenést. ${ }^{40}$ Projevem brzkého zavedení technologií může být nemožnost/komplikovanost dalšího rozvoje z toho důvodu, že se technologický vývoj ubral jiným směrem. Uzamčení ostatními uživateli a osobní uzamčení je lock-in projevující se využíváním řešení, které nemusí být pro daného zadavatele nejvýhodnější, ale využívá se proto, že toto řešení je $\mathrm{v}$ prvním případě vhodné pro skupinu, se kterou zadavatel musí spolupracovat, a v případě druhém z důvodu (nezřídka iracionálních) preferencí.

Vysoké náklady na změnu, byṫ jsou většinově chápány jako svébytná forma uzamčení, ${ }^{41}$ zároveň představují i nepřímý projev výše uvedených lock-in efektů. Náklady na změnu navíc mohou představovat jakousi měrnou jednotku uzamčení, kdy čím větší jsou, tím větší je i míra lockinu. $^{42}$ Všechny výše uvedené projevy staví zadavatele do těžké pozice nejen z hlediska vyjednávání s novými, potenciálními, dodavateli, ale i dodavatelem současným, a to z hlediska managementu stávajících zakázek i zadávání zakázek nových, navazujících.

40 BRÁZDIL, Martin. Rizika smluv o cloudových službách. PRÁVNÍ PROSTOR.CZ [online]. ATLAS consulting spol. s r.o., publikováno 28. 3. 2016 [cit. 6. 1. 2018].

${ }^{41} \mathrm{~K}$ tomu viz např. FARRELL; KLEMPERER, op. cit., s. 1972 - 1974.

${ }^{42}$ Srov. SHARPE, Nicola; AREWA, Olufunmilayo. Is Apple Playing Fair? Navigating the iPod FairPlay DRM Controversy. Northwestern Journal of Technology and Intellectual Property. [online]. 2007, vol. 5, s. 342 [cit. 21. 10. 2017]. 
Dalším nepřímým projevem lock-inu, představujícím už jeho řešení, at už dočasné či trvalé, může být insourcing. Ten je ne vždy možný (např. při rozvoji řešení, které je chráněno právy duševního vlastnictví) a ne vždy ekonomicky výhodný (lze si jen těžko představit, že by veřejný zadavatel začal vyrábět vlastní procesory nebo grafické karty, aby předešel technologické závislosti nebo „early adopters“ lock-inu - teoretická možnost však existuje). Problémem také je, že veřejná správa často nemůže platovými podmínkami konkurovat mzdovým podmínkám soukromé sféry, což značně ztěžuje zajištění odborníků potřebných k provedení insoucingu (např. správců systémů, analytiků nebo programátorů). Ze soukromého sektoru můžeme zmínit například společnost Wal-Mart, která si v rámci insourcingu vytvořila svou vlastní platformu pro cloud management, aby proprietárnímu uzamčení předešla. ${ }^{43}$ Zároveň je třeba zdůraznit, že byt insourcing může být nepřímým projevem a řešením lock-inu, nelze říci, že by insourcingu uzamčení muselo předcházet vždy. Insourcing může být zvolen $\mathrm{z}$ nejrůznějších ekonomických, právních, ale i politických nebo osobních důvodů, bez ohledu na riziko uzamčení. Zvláštní formou insourcingu, typickou pro veřejný sektor, je in-house zadávání (někdy též nazývané interní zadávání) dle $§ 11$ ZZVZ. $^{44}$

In-house zadávání, v ZZVZ definované jako vertikální spolupráce, představuje výjimku definující situaci, kdy se uzavření smlouvy nepovažuje za zadání veřejné zakázky - situaci, kdy není nutné uskutečnit zadávací řízení dle ZZVZ. ${ }^{45}$ Zákon pro možnost využití in-house zadávání stanoví tři kumulativní podmínky. Zadavatel může tohoto nástroje využít, pokud i) tuto osobu sám (nebo společně s jinými veřejnými zadavateli) ovládá obdobně jako své vnitřní organizační jednotky, ii) je jediným (případně jediným s dalšími ovládajícími veřejnými zadavateli) kdo má v takto ovládané osobě

43 SEROTER, Richard. Everything Is "Lock-In": Focus on Switching Costs. InfoQ.com [online]. C4Media Inc., publikováno: 8. 6. 2016 [cit. 25. 10. 2017].

${ }^{44}$ Úprava v § 11 ZZVZ se vztahuje na veřejné zadavatele; úprava pro sektorové zadavatele je odchylná.

${ }^{45}$ Blíže k in-house zadávání viz např. RAFAJ, Petr; FRIČOVÁ, Vítězslava. Vybrané instituty práva veřejných zakázek $\mathrm{v}$ judikatuře Soudního dvora $\mathrm{EU}$ a jejich úprava v nových zadávacích směrnicích. Bulletin advokacie. 2015, č. 9, s. 39-44. ISSN 1210-6348. 
majetkovou účast a zároveň iii) plnění úkolů, které osobě byly svěřeny ovládajícím veřejným zadavatelem (nebo ovládajícími veřejnými zadavateli nebo jinými právnickými osobami, které ovládající veřejný zadavatel nebo veřejní zadavatelé rovněž ovládají jako své vnitřní organizační jednotky), tvoří více než 80 \% celkové činnosti takto ovládané osoby. ${ }^{46,47}$

Úprava in-house zadávání však nemusí být $\mathrm{v}$ praxi zcela dostačující. Typickým př́́kladem jsou dva státní podniky - Národní agentura pro komunikační a informační technologie, s. p. (dále jen „NAKIT“) a Státní pokladna Centrum sdílených služeb, s. p. (dále jen „SPCSS“). NAKIT byla zřízena Ministerstvem vnitra a je to právě Ministerstvo vnitra, kdo splňuje podmínky ovládajícího veřejného zadavatele vůči NAKIT, jakožto ovládanému dodavateli. Obdobný vztah je mezi SPCSS a Ministerstvem financí. Ministerstva, jakožto veřejní zadavatelé, mohou mít zájem využít in-house zadávání. Vzhledem k tomu, že jsou ministerstva organizačními složkami státu na stejné úrovni, nemůže dle současné právní úpravy jedno ministerstvo přímo využít státní podnik spadající pod jiné ministerstvo. Nejsou totiž splněny podmínky dané $\S 11$ ZZVZ. Tento zpưsob in-house zadávání není možný ani přesto, že by to z pohledu státního rozpočtu mohlo být výhodné. Ministerstvo vnitra tak může využívat in-house zadávání a uzavírat smlouvy s NAKIT, aniž by tyto smlouvy byly považovány za veřejné zakázky, nikoli však s SPCSS. Ministerstvo financí pak může využívat in-house výjimky a uzavírat smlouvy s SPCSS mimo režim ZZVZ, nikoli však s NAKIT. Takovýto př́stup může být $\mathrm{v}$ rozporu s principem $3 \mathrm{E}$ a takto restriktivně pojatá výjimka in-house zadávání může značně limitovat možné pozitivní dopady na hospodaření veřejných zadavatelů. Odstranění tohoto problému může být dosaženo např. úpravou ZZVZ, konkrétně vložením odst. 7 do $\S 11$, který by mohl znít následovně: „Pro účely odst. 1 se na osobu, jež je ovládána jinou organizační složkou státu na stejné horizontální úrovni jako veřejný zadavatel, hledí, jako by ji veřejný zadavatel ovládal sám.“

${ }^{46}$ Pro dosažení kontroly ze strany veřejného zadavatele musí mít zadavatel nejen podíl na základním kapitálu ovládané osoby, ale i účast na rídících orgánech této osoby. Cit. z: HERMAN, Pavel; FIDLER, Vlastimil; ADÁMKOVÁ, Markéta a kol. Komentář k zákonu o zadávání veřejných zakázek. 2. vyd. Plzeň: Aleš Čeněk, 2016, s. 35.

$47 \S 11 \mathrm{ZZVZ}$. 
Řešením těchto situací bez změny zákona může být to, že je zajištění daného (poptávaného) plnění přeneseno na jiné ministerstvo tak, aby mohl být $\mathrm{v}$ režimu in-house využit ten daný státní podnik, který se k zajištění daného plnění jeví jako nejvhodnější. Takovéto konstrukce jsou přinejmenším $\mathrm{z}$ administrativního, legislativního a koordinačního hlediska velmi náročné. Proto se lze domnívat, že by měly být současné právní předpisy upraveny tak, aby obdobné konstrukce nebyly nutné, a to právě s odkazem na princip $3 \mathrm{E}$ a na zjevnou neopodstatněnost takto úzce pojaté výjimky. Takovéto konstrukce tak mohou rovněž nepřímo ukazovat na potýkání se s problémem proprietárního uzamčení.

Je-li zadavatel závislý pouze na jednom dodavateli, je velmi pravděpodobné, že se toto jako nepř́mý projev promítne i do jeho efektivity a produktivity. Pokud dva zadavatelé vykonávající obdobnou činnost a pro tuto činnost zvolí dvě různá řešení, přičemž jedno řešení v budoucnu povede k proprietárnímu uzamčení zadavatele a druhé nikoli, je možné, že „uzamčený“ zadavatel nebude schopný dané řešení rozvíjet tak efektivně, jako zadavatel druhý. $V$ konečném důsledku tak toto řešení může být zastaralé, ${ }^{48}$ nákladnější na provoz, méně uživatelsky přívětivé, popř. bude pro jeho provoz nutný větší počet pracovníků či pracovníci s vysokou odborností nebo specifickým know-how.

Příklady nástrojů $\mathrm{k}$ vytvoření/udržení/posílení lock-inu, které jsou dodavateli využívány, jsou tržní síla a technologická dominance. Čím větší tržní sílu daný dodavatel má, tím snáze se mu, za standardních podmínek, uzamčení vytvář́, nebot̉ nejen, že má nižší počet konkurentů, ale často je jediným, kdo je schopen splnit podmínky kvalifikace pro zadávací rízení (např. předložit požadované reference) nebo nabídnout nejnižší cenu za soutěžené plnění. ${ }^{49}$ Tato nejnižší cena však může být výhodná jen $\mathrm{v}$ daném čase, nikoli z dlouhodobého hlediska, jak bude blíže vysvětleno v následují-

48 CASTELLI, op. cit., s. 135.

49 Blíže k tržní síle viz např. NEJEZCHLEB, Kamil; HAJNÁ, Zuzana. Stanovení tržní síly a její význam v soutěžním právu. Časopis pro právní vědu a praxi. [Online]. 2013, č. 4, s. 515-524. [cit. 21. 3. 2018] nebo VARIAN, Hal R.; FARRELL, Joseph; SHAPIRO, Carl. The Economics of Information Technology: An Introduction. New York: Cambridge University Press, 2004, s. 15-42. 
cí kapitole. Tržní síla je zároveň dobrým předpokladem pro podporu dalšího vývoje nových technologií, jež mohou být díky jedinečné pozici dodavatele např. nejdříve implementovány $\mathrm{v}$ soukromém sektoru a veřejný sektor se tak ocitne $\mathrm{v}$ uzamčení ostatními uživateli. ${ }^{50}$ Tržní síla také může být jedním z předpokladů pro technologickou dominanci, nebot může poskytnout dostatečné ekonomické prostředky pro výzkum a vývoj. Jak tržní síla, tak technologická dominance staví dodavatele do konformní pozice, jež se projevuje tak, že dodavatel nemusí soutěžit s dalšími účastníky, nebo že je počet účastníků, oproti jiným veřejným zakázkám, významně redukován a nabídková cena dodavatele tak může být podstatně vyšší, než by byla, kdyby docházelo $\mathrm{k}$ plnohodnotné hospodářské soutěži. I tyto situace tak můžeme označit za projevy proprietárního uzamčení.

Snahu utvořit uzamčení je možné odhalit za pomocí formálních indikátorů budování lock-inu ze strany dodavatele. Mezi tyto formální indikátory patří např̀. situace, kdy se dodavatel snaží budovat vendor lock-in za použití neopodstatněných ustanovení o mlčenlivosti nebo rozšiřováním ochrany duševního vlastnictví nad rámec zákonných institutů..$^{51}$ Dále se tato snaha projevuje redukcí smluvních pokut a formulací dalších jednostranně výhodných ujednání a podmínek, ${ }^{52} \mathrm{kdy}$ dodavatelé při jejich vyjednávání - dialogu mezi zadavatelem a dodavatelem - uplatňují svou tržní sílu nebo využívají svých výhradních práv duševního vlastnictví. ${ }^{53}$

50 Veřejný sektor by pak na toto uzamčení ostatními uživateli, ukázalo-li by se jako nevhodné se tomuto lock-inu bez dalšího podřídit, musel reagovat např. marketingovou kampaní za účelem zvýšení počtu uživatelů jím preferovaného řešení.

51 Blíže k problematice práv duševního vlastnictví, konkrétně k právní regulaci počítačových programů a veřejných zakázek, viz POREMSKÁ, Michaela. ICT in Public Procurement Can Lead to Cybercrimes?. Masaryk University Journal of Law and Technology [Online]. 2014, vol. 4, no. 2, s. 166-168. [cit. 26. 10. 2017].

52 Srov. TER, Kah Leng. Path Dependence, Lock-in and Lock-out Agreements. Singapore Academy of Law Journal [Online]. 1992, vol. 4, s. 349-358. [cit. 26. 10. 2017].

53 Naproti tomu můžeme v současné době sledovat i případy, kde tlak na ,antivendor lock-in“ donutil některé dodavatele vytvořit sít spolupracujících dodavatelů. Tito dodavatelé mezi sebou mohou řádně soutěžit. Na trhu se tak zvyšuje počet soutěžitelů, byt se nemění počet subsitutů. Takovým př́kladem je GORDIC Partner Program. K tomu viz webovou stránku: GORDIC Partner Program [online]. GORDIC spol. s.r.o. [cit. 26. 3. 2018]. 


\section{PRÁVNÍ MOŽNOSTI PŘEDCHÁZENÍ VENDOR LOCK-INU PŘI PŘÍPRAVĚ ZADÁVACÍ DOKUMENTACE}

V předcházejících kapitolách byly popsány zásadní problémy, jež jsou s lock-in efektem spojeny. Je proto beze sporu, že ideální je uzamčení včas předejít. Při zadávání veřejných zakázek v oblasti ICT je třeba mít vždy na paměti specifičnost tohoto odvětví, ale i jednotlivých pododvětví. Je samozřejmostí, že je třeba přistupovat rozdílně $\mathrm{k}$ veřejným zakázkám na služby a na dodávky, stejně tak je ale třeba přistupovat rozdílně $\mathrm{k}$ dodávkám softwaru a hardwaru, cloudovým a desktopovým řešením, jednorázovým řešením nebo řešením s nutností dalšího rozvoje a údržby.

Při zadávání ICT veřejných zakázek je dưležité vždy zvážit dobu, na kterou je zamýšlené řešení pořizováno. ${ }^{54}$ Vycházejme z předpokladu, že v rámci zajištění principu $3 \mathrm{E}$ je obecně zájmem zadavatele pořídit řešení na co nejdelší možnou dobu. Vzhledem k technologickému, případně i právnímu, ekonomickému nebo třeba společenskému vývoji je však velmi pravděpodobné, že postupem času bude toto řešení třeba více, či méně upravit, opravit nebo částečně zaměnit. Zadávací rízení by tak mělo být nastaveno takovým způsobem, aby bylo vybráno řešení, které bude výhodné nejen $\mathrm{v}$ době pořízení, ale $\mathrm{i} v$ době provozu a $\mathrm{v}$ době případné nutnosti dalšího rozvoje.

V praxi se můžeme setkat s tendencí zadavatelů k pořizování řešení, které se skládá z různých komponentů, přičemž je uváděn požadavek, aby všechny tyto komponenty byly od stejného výrobce. Jako př́klad lze uvést sestavu počítače, monitoru, počítačové myši a klávesnice. Za důvod tohoto požadavku uvádějí zadavatelé předpoklad nejvyšší možné kompatibility. Bez ohledu na to, zda tento požadavek nemůže být vůči některým účastníkům diskriminační a zda tento požadavek koresponduje s principem 3E $\mathrm{v}$ době pořízení tohoto řešení, je třeba poukázat na fakt, že takové řešení se rozhodně nemusí ukázat jako hospodárné v budoucnu, ve chvíli, kdy některý $\mathrm{z}$ těchto komponentů bude třeba vyměnit. $\mathrm{V}$ př́padě, že by vybraný dodavatel nedisponoval standardizovaným hardwarem, nebo by hardware ne-

${ }_{54}$ Srov. např. HORKÝ, op. cit., s. 33-47. 
byl ani oddělitelný, došlo by k uzamčení z důvodů inkompatibility a následných nákladi̊ na změnu. Obdobný problém může vyvstat za situace, kdy by později pořízený software nebyl kompatibilní s dřive pořízeným hardwarem, at už by se jednalo o různé operační systémy pro počítače a mobilní telefony nebo o programy a aplikace. Lze tak doporučit, v rámci definování předmětu veřejné zakázky, poptávat standardizovaný hardware, aby jeho komponenty bylo možné snadno a ekonomicky vyměnit. ${ }^{55}$ Při pořizování softwaru lze doporučit takový software, který je kompatibilní s používaným hardwarem a softwarem v dané době, a který bude pravděpodobně kompatibilní i s případně nově pořízenou technologií.

V oblasti softwaru může být vhodné používat open source operační systémy, programy a aplikace, tedy software, jehož zdrojový kód je na základě poskytnuté licence možné volně upravovat, a který je navíc ve většině případů zdarma. Otázkou zůstává, zda jsou tato otevřená řešení použitelná pro všechny potřeby veřejných zadavateli̊ a zda jeho případné nedostatky nepřináší skryté náklady, které mohou převýšit náklady na pořízení softwaru placeného. $^{56}$

Úvaha o výše uvedených aspektech zadávacího řízení v oblasti ICT, jež svůj odraz najdou zejména $v$ definici předmětu veřejné zakázky, by se měla promítnout v podmínkách kvalifikace, kritériích hodnocení - těmto dvěma institutům je $\mathrm{z}$ důvodu jejich důležitosti věnován zvláštní prostor v následujících dvou podkapitolách - a technických, obchodních a zvláštních podmínkách. ${ }^{57}$ Efektivní promítnutí takovýchto úvah do těchto částí zadávací dokumentace představuje právní možnosti předcházení lock-in efektu. ${ }^{58}$

55 Srov. EBBESSON, Bjöm; OISSON, Thomas. Managing divergences in IT infrastructure standardization [online]. Göteborg, 2018, s. 12-16 [cit. 1. 11. 2017]. Master thesis in IT management. IT University of Göteborg, Chalmers University of Technology and University of Gothenburg.

56 Blíže k využití open source ve veřejné správě viz: TRIDLA, Radek. Potenciál a limity využití open source ve veřejné správě [online]. Brno, 2012 [cit. 1. 11. 2017]. Bakalářská práce. Masarykova univerzita, Ekonomicko-správní fakulta. Vedoucí práce David ŠPAČEK.

$57 \S 37$ odst. 1 ZZVZ.

${ }^{58} \mathrm{~K}$ tomu viz také Nevýhodná ujednání ve smlouvách na dodávku ICT produktů [online]. Odbor Hlavního architekta eGovernmentu Ministerstva vnitra, 2017, 3 s. [cit. 25. 12. 2018]. 
V rámci předcházení proprietárnímu uzamčení při přípravě zadávací dokumentace hraje významnou roli i úvaha o tom, jaká práva si veřejný dodavatel hodlá vyhradit, zvláště jedná-li se o dílo ve smyslu autorského zákona. ${ }^{59}$ Dostatečné vyhrazení těchto práv výrazně snižuje možnost vzniku uzamčení. Rozsah těchto práv může být představován různě pojatými licenčními ujednáními, ale i kompletním oprávněním $\mathrm{k}$ výkonu majetkových práv autorských formou jejich postoupení na zadavatele. ${ }^{60}$ Využití institutu postoupení předpokládá pečlivou analýzu každého konkrétního případu, nebot čím exkluzivnější oprávnění, která bude zadavatel požadovat, budou, tím vyčší bude pravděpodobně i cena nabízeného řešení. Využití institutu postoupení je ve většině př́ípadů bohužel vyloučeno pro již existující proprietární software, nebot jde o komerční produkty nabízené více osobám, např. na bázi EULA („End-User-License-Agreement“) licencí. U těchto licencí zpravidla není možné takové oprávnění udělit, anebo udělení takového oprávnění nelze spravedlivě požadovat. ${ }^{61}$

Obecně můžeme říci, že čím delší je plánovaná doba užití, tím pravděpodobnější bude nutnost rozvoje a zásahu do systému a oprávnění by tak měla být rozsáhlejší. Vždy je však nutné analyzovat a co nejpřesněji odhadnout ekonomické dopady jednotlivých řešení. Rozsah oprávnění, který je vhodné požadovat, se rovněž liší v závislosti na formě poptávaného plnění. Je třeba rozlišovat, zda bude obsahovat pouze samotné dodání (zde bude vyhrazení širokého katalogu práv většinou vhodnější), nebo i provoz a př́ípadný rozvoj. ${ }^{62}$

Mezi další nástroje pro minimalizaci rizika lock-inu patří dělení větších zakázek (nesmí zde však docházet k účelovému obcházení zákona např. ve smyslu posuzování nadlimitních a podlimitních veřejných zakázek) a pří-

\footnotetext{
${ }^{59}$ Výhradu práv je třeba důkladně ošetřit zvláště u softwarových řešení.

${ }^{60}$ V návaznosti na licenční ujednání pak bývá vhodné i vyžádání zdrojového kódu, a to v adekvátní podobě (zakázána by měla být např. minifikace a obdobné „ochranné“ postupy).

${ }^{61} \mathrm{KMOCH}$, Ondřej. IT veřejné zakázky - co zvažovat při aplikaci postoupení oprávnění $\mathrm{k}$ vý konu majetkových práv autorských a dílčí zamyšlení na závěr. EPRAVO.CZ [online]. EPRAVO.CZ, a.s., publikováno 29. 1. 2016 [cit. 1. 11. 2017].

62 Ibid.
} 
prava strategických zakázek v dialogu s potenciálními dodavateli. ${ }^{63}$ Dále je vhodné stanovit jako součást předmětu plnění i poskytnutí úplné technické dokumentace, opce na školení v dané architektuře a na administraci daného řešení. Dalším opatřením, které by mělo být zváženo, je modulární plánovaní, kdy klientská rozhraní a jednotlivé moduly komunikují výhradně skrze standardizovaná rozhraní/řešení (tzv. open standardy) ${ }^{64}$ a jsou tak nahraditelná produkty třetích stran - dalších potenciálních dodavatelů. ${ }^{65}$ Za hlavní přednost open standardů se uvádí interoperabilita. ${ }^{66,67}$ Interoperabilitu je možné chápat mimo jiné jako schopnost práce s danými formáty napříč aplikacemi, používání SLA („Service-Level-Agreement“) šablon a sjednocených autentizačních a autorizačních formátů tokenů. ${ }^{68} \mathrm{Na}$ rozvoj interoperability výslovně pamatuje např. i GDPR. ${ }^{69}$ Na základě výše uvedeného můžeme uzavřít, že řádné vymezení rozsahu a předmětu veřejné zakázky je zásadním krokem pro předejití lock-inu.

\subsection{VENDOR LOCK-IN A PODMÍNKY KVALIFIKACE}

Podmínky kvalifikace, jakožto podmínky účasti v zadávacím řízení, jsou jedním z nástrojů, jehož kvalitním nastavením je možné přispět $\mathrm{k}$ předcházení proprietárního uzamčení. Jedná se o nástroj, který by měl být maximálně efektivně využit již v prvopočátku procesu uzavírání obchodního vztahu mezi zadavatelem a dodavatelem veřejné zakázky. Vzhledem

63 SKUHROVEC, op. cit., s. 18.

${ }^{64}$ K tomu viz také WEST, Joel. The Economic Realities of Open Standards: Black, White and Many Shades of Gray. In: GREENSTEIN, Shane; STANGO; Victor (eds.). Standards and Public Policy [Online]. Cambdridge: Cambridge University Press, 2005, s. 1-29 [cit. 21. 3. 2018].

65 Metodický pokyn CHJ č. 3. - Metodika veřejného nakupování: Naplňování principu 3E v praxi veřejného zadávání [online]. Publikováno 7. 7. 2016 [cit. 6. 11. 2017].

66 SUTOR, Robert. Software Standards, Openness, and Iteroperability. In: DeNaris, Laura (ed.). Opening Standards: The Global Politics of Interoperability. Cambdridge, Massachusetts: The MIT Press, 2011, s. 209-218.

67 K interoperabilitě (při cloud computingu) viz také Opinion 05/2012. Article 29 Data Protection Working Party [online]. Přijato 1. 7. 2012, s. 5 a 16 [cit. 26. 12. 2018].

68 HARSH, Piyush, DUDOUET, Florian, CASCELLA, Roberto a kol. Using Open Standards for Interoperability - Issues, Solutions, and Challenges facing Cloud Computing [online]. 2012, s. 1-6 [cit. 6. 11. 2017].

69 Odst. č. 68 recitálu GDPR. 
k systematice ZZVZ, kde je kvalifikace upravena pro zadávací podmínky v nadlimitním režimu (aplikovatelné též na režim podlimitní), jsou podmínky kvalifikace v tomto článku rozebírány právě z pohledu nadlimitního režimu v otevřeném řízení (obdobně je postupováno i u další části - př̌i popisu kritérií hodnocení).

Kvalifikace se dělí na způsobilost - oprávnění - a samotnou kvalifikaci lepší, či horší schopnost. ${ }^{70}$ Způsobilost se skládá ze způsobilosti základní a profesní, kvalifikace se pak dělí na ekonomickou a technickou. Základní a profesní způsobilost musí zadavatel požadovat obligatorně, zatímco ekonomickou a technologickou kvalifikaci jen fakultativně. ${ }^{71}$

Jsou to však právě ICT veřejné zakázky, kde požadování technické kvalifikace dává snad největší smysl. Pokud se zadavatel pro požadování technické kvalifikace rozhodne, musí stanovit její požadovaný rozsah (kritéria), minimální úroveň a údaje, doklady, vzorky anebo modely sloužící $\mathrm{k}$ jejímu prokázání. Kritéria technické kvalifikace a jejich prokázání jsou stanovena v § 79 ZZVZ (seznam možných kritérií je taxativní) a slouží k prokázání lidských zdrojů, technických zdrojů nebo odborných zkušeností nezbytných pro plnění veřejné zakázky. Tyto požadavky jsou také nejvíce spojeny se schopností dodavatele provést dané plnění, a to navíc konkrétním požadovaným způsobem. ${ }^{72}$ U ICT veřejných zakázek tak mohou prokázat zkušenost s obdobným typem zakázky, jejím dalším rozvojem, ale i schopnost využívat open standardy ${ }^{73}$ nebo schopnost vyhovění požadavkům modulárního plánování apod. $\mathrm{K}$ tomu je vhodné požadovat zejména seznam významných dodávek nebo významných služeb, seznam techniků nebo technických útvarů podílejících se na plnění, osvědčení o vzdělání o od-

${ }^{70}$ BOROŠOVÁ, Hana; ŠEBESTA, Milan. Kvalifikace $\mathrm{v}$ otevřeném řízení dle návrhu zákona o zadávání veřejných zakázek. EPRAVO.CZ [online]. EPRAVO.CZ, a.s., publikováno 11. 12. 2015 [cit. 20. 11. 2017].

$71 \S 73$ odst. 2 ZZVZ.

72 DVOŘÁK, David; MACHUREK, Tomáš; NOVOTNÝ, Petr a kol. Zákon o zadávání veřejných zakázek. Komentár. Praha: Nakladatelství C. H. Beck, 2017, s. 493.

${ }^{73} \mathrm{~K}$ open standartům viz také GHOSH, Rishab. An Economic Basis for Open Standards. In: DeNaris, Laura (ed.). Opening Standards: The Global Politics of Interoperability. Cambdridge, Massachusetts: The MIT Press, 2011, s. 75 - 97. nebo GLADER, Marcus. Open standards: Public Policy aspects and competition law requirements. European Competition Journal [Online]. 2010, vol. 6, no. 1, s. 611-648 [cit. 28. 11. 2017]. 
borné kvalifikaci a případně i doklady prokazující shodu požadovaného výrobku s požadovanou technickou normou nebo dokumentem.

Veškeré požadavky musí být stanoveny přiměřeně ke složitosti a rozsahu předmětu veřejné zakázky, $\mathrm{v}$ souladu se zásadami zadávání veřejných zakázek a bez vytváření bezdůvodných překážek hospodářské soutěže. $\mathrm{K}$ důvodnosti/přiměřenosti požadavků se vyjádřil Úřad pro ochranu hospodářské soutěže např. ve svém rozhodnutí ze dne 22. 5. 2014, č. j. ÚOHSS140/2014/VZ-10908/2014/531/Olu/LFr, kdy konstatoval, že dodávka výpočetní techniky je stejně náročná $\mathrm{v}$ soukromém sektoru jako v sektoru veřejném a tudíž je požadavek zadavatele na dodání referencí $\mathrm{k}$ dodávkám výpočetní techniky pro státní sféru zpravidla neopodstatněný.

Obecně by se požadavky zadavatele měly vztahovat $\mathrm{k}$ nejpodstatnější části předmětu plnění, a to nejen obsahově, ale ve většině případů i kvantitativně. Mohou však nastat situace, kdy jako oprávněné budou shledány i požadavky vztahující se k marginální části plnění, pokud bude představovat požadavek vhodný/opodstatněný. ${ }^{74}$ Např. v případě technologického řešení zpracovávající osobní údaje, byt se jedná jen o vedlejší činnost, která je tímto řešením zajištěna, by za určitých okolností mohlo být považováno za opodstatněné prokázání schopnosti přijmout dostatečná technická opatření pro zajištění odpovídající ochrany osobních údajů a práv subjektů údajů.

Je třeba zdůraznit, že prokázání splnění technické kvalifikace automaticky nezajištuje tento stav po dobu plnění zakázky. Je proto vhodné podmínky kvalifikace provázat i s podmínkami obchodními, kde je toto možné ošetřit smluvně. To může být navíc zajištěno systémem smluvních pokut.

\subsection{VENDOR LOCK-IN A KRITÉRIA HODNOCENÍ}

ZZVZ ukládá povinnost hodnotit nabídky dle ekonomické výhodnosti. ${ }^{75}$ Ekonomická výhodnost se stanoví na základě nejvhodnějšího poměru nabídkové ceny a kvality včetně nákladů životního cyklu. Byt̉ je, až na výjimky, možné stanovit ekonomickou výhodnost pouze na základě nejnižší

74 DVOŘÁK; MACHUREK; NOVOTNÝ a kol., op. cit., s. 495.

${ }^{75} \S 114$ odst. 1 ZZVZ. 
nabídkové ceny, u veřejných zakázek na ICT toto obecně není vhodný postup, nebot ZZVZ dává dodavateli řadu nástrojů pro vybrání toho nejlepšího dodavatele na základě řady dalších, ve většině případů vhodnějších, kritérií. Jejich nevyužití může způsobit rozpor s principem 3E. Kritériem kvality v oblasti ICT může být zejména technická úroveň, funkční vlastnosti, uživatelská př́stupnost, inovační aspekty, kvalifikace nebo zkušenosti osob podílejících se na zakázce, úroveň servisních služeb včetně technické pomoci, nebo podmínky a lhůta pro dodání plnění.

Zajímavou možností je rovněž stanovení pevné ceny a hodnocení pouze kvality. Tento postup však vzhledem k principu $3 \mathrm{E}$ pravděpodobně nebude v ICT zakázkách běžným, nebơ si lze jeho opodstatní představit jen zř́́dka. Obzvláště vhodným kritériem jsou pak náklady na životní cyklus, nebot mohou odrážet např. náklady na údržbu nebo náklady spojené $s$ koncem životnosti plnění.

Kritéria nemohou být pouze vyjmenovaná, ale musí být stanovena jejich váha (v procentech nebo prostřednictvím matematického nebo jiného vztahu) a není-li zadavatel váhu schopný určit, pak alespoň pořadí hodnotících kritériî. ${ }^{76}$ Kritéria musí být uvedena jasně a jednoznačně. Musí být tedy specifikováno, jak budou kritéria posuzována. Mělo by být uvedeno nejen, čím se zadavatel při hodnocení bude zabývat, ale i to, co je vyžadováno $\mathrm{v}$ případě technického řešení na upgrade telekomunikačních služeb např. typ ústředny nebo s čím by mělo být požadované řešení kompatibilní. Při tvorbě hodnotících kritérií je třeba dbát nejen na to, aby bylo definováno, jaké vlastnosti jsou žádoucí, ale i na to, aby byly eliminovány vlastnosti nežádoucí. ${ }^{77}$ Zároveň je třeba mít na paměti, že totožné kritérium nemůže představovat podmínku kvalifikace a zároveň kritérium hodnocení v jedné veřejné zakázce.

$76 \S 115$ ZZVZ.

77 FRANCOVÁ, Anna. Kritéria hodnocení nabídek ve veřejných zakázkách. PRÁVNÍ PROSTOR.CZ [online]. ATLAS consulting spol. s r.o., publikováno 9. 3. 2017 [cit. 7. 1. 2018]. 


\section{JEDNACÍ ŘÍZENÍ BEZ UVEŘEJNĚNÍ V APLIKAČNÍ PRAXI}

Nepodaří-li se uzamčení předejít, je třeba přijít $s$ jeho následným řešením. Možností řešení (at’ už dočasnou či trvalou) již vzniklého lock-in efektu může být, za splnění zákonem stanovených podmínek, zadání veřejné zakázky formou JŘBU. To je upraveno v § 63 a násl. ZZVZ, a to v souladu se zadávacími směrnicemi. $^{78} \mathrm{~V}$ souvislosti s lock-in efektem je pak relevantní především $\S 63$, odst. 3 a $4^{79}$ upravující podmínky, které musí být splněny pro využití JŘBU, a které jsou zároveň aplikovatelné ve vztahu k proprietárnímu uzamčení:

„(3) Zadavatel může také použít jednací řizení bez uveřejnění, pokud veřejná zakázka může být splněna pouze určitým dodavatelem, nebot'

a) předmětem plnění veřejné zakázky je jedinečné umělecké dílo nebo výkon,

b) z technických důvodů neexistuje hospodářská soutěž, nebo

c) je to nezbytné z duvodu ochrany výhradních práv včetně práv duševního vlastnictví.

78 Relevantní ustanovení zadávací směrnice č. 2014/24/EU ze dne 26. 2. 2014: „Čl. 32: Ve zvláštních př́padech a za okolností uvedených v odstavcích 2 až 5 mohou členské státy stanovit, že veřejní zadavatelé mohou zadávat veřejné zakázky $v$ jednacím ř́zení bez uveřejnění.

Čl. 32: Jednací řízení bez uveřejnění může být použito pro veřejné zakázky na stavební práce, dodávky a služby $v$ následujících př́padech:

(...)

b) jestliže stavební práce, dodávky nebo služby mohou být z některého $\mathrm{z}$ následujících důvodů dodány jen konkrétním hospodářským subjektem:

i) cílem veřejné zakázky je vytvoření nebo získání jedinečného uměleckého díla nebo uměleckého výkonu,

ii) hospodářská soutěž z technických důvodů neexistuje,

iii) ochrana výhradních práv včetně duševního vlastnictví.

Výjimky uvedené $v$ bodech ii) a iii) se použijí jen $v$ případě, že neexistuje přiměřená alternativa nebo náhrada a že neexistence soutěže není výsledkem umělého zúžení parametrů veřejné zakázky;

pokud je to nezbytně nutné, když z důvodů krajní naléhavosti způsobené událostmi, které veřejný zadavatel nemohl předvídat, nelze dodržet lhůty pro otevřené řízení, užší řízení nebo jednací řízení. Okolnosti pro odůvodnění krajní naléhavosti nesmějí být v žádném případě způsobeny veřejným zadavatelem.“

K tomu viz blíže ARROWSMITH, Sue. The Law of Public and Utilities Procurement. Vol. 1, ed. 3. London: Thomson Reuters, 2014, s. 1065-1072.

79 Ve vztahu k lock-in efektu mohou být relevantní také např. ustanovení § 64 písm. b) (pro dodávky) nebo § 66 (pro služby). 
(4) Podmínky podle odstavce 3 písm. b) a c) jsou splněny pouze $v$ takovém př́padě, že nelze využít jiného postupu a že zadavatel nestanovil zadávací podmínky veřejné zakázky s cílem vyloučit hospodářskou soutěž."

Je třeba zdůraznit, že podmínky pro využití JŘBU musí splňovat celý předmět veřejné zakázky, ne tak jen část poptávaného plnění. ${ }^{80}$ Za zakázku dle $\S 63$ odst. 3 písm. a) může být považováno např. rozšíření audiovizuálního průvodce doplněného o ilustrace. Odst. 3 písm. b) je pak hlavním nástrojem používaným při uzamčení z důvodu inkompatibility a ustanovení písm. c) téhož odstavce je využitelné např. pro rozšíření informačního systému, který je chráněn jako autorské dílo.

Zvláštní pozornost je třeba věnovat právě odst. 4 citovaného ustanovení, který pro použití výše uvedeného odstavce 3 písm. b) a c) stanovuje předpoklad, že zadavatel nemohl využít jiného postupu a zároveň nestanovil zadávací podmínky veřejné zakázky $\mathrm{s}$ cílem vyloučit hospodářskou soutěž. Vyloučení hospodářské soutěže by totiž vedlo $\mathrm{k}$ diskriminaci, a tedy $\mathrm{k}$ porušení jedné ze zásad ZZVZ. Toto ustanovení nebylo přímo zakotveno $\mathrm{v}$ předešlé právní úpravě. ${ }^{81}$ Vzhledem $\mathrm{k}$ účelu zákona a dodržování $\mathrm{v}$ něm obsažených zásad však bylo toto hledisko běžně zohledňováno soudy i Úřadem pro ochranu hospodářské soutěže, nebot by se $\mathrm{v}$ opačném případě jednalo o obcházení zákona. Např. Nejvyšší správní soud ve svém rozsudku ze dne 11. 1. 2013, č. j. 5 Afs 42/2012 - 53 uvádí: „V postupu žalobce není možno shledávat účelovost a úmysl obejití zákona o veřejných zakázkách př̀ zadávání návazných veřejných zakázek. Původní veřejné zakázky zadával zadavatel prokazatelně, aniž by měl vědomí o tom, že v budoucnu mu vznikne potřeba zadat dotčené veřejné zakázky. Rovněž je tréba zdưraznit, že stav exkluzivity nebyl vytvořen zadavatelem a nevznikl samoúčelně jako $v$ odkazovaných př́padech, ale byl přirozenou součástí předmětu plnění, resp. neoddělitelným důsledkem toho, že v rámci předmětu plnění vznikala autorská díla ve smyslu ustanovení $\& 2$ autorského zákona.“

\footnotetext{
80 Rozhodnutí Úřadu pro ochranu hospodářské soutěže ze dne 13. 11. 2014, č. j. S751/2014/VZ-24208/2014/542/JVO.

81 Srov. § 23 zákon č. 137/2006 Sb.
} 
Vzhledem k tomu, že tato podmínka nebyla v zákoně č. 137/2006 Sb., ve znění pozdějších předpisů, explicitně zakotvena, mohlo její uplatnění činit potíže, jak bude přiblíženo dále. Podmínku, že nelze využít jiného postupu, je třeba interpretovat jako neexistenci přměřené alternativy. To znamená, že zadavatel nemůže $\mathrm{z}$ technických důvodů poptávat jiné řešení, resp. takové řešení by představovalo nutnost vynaložení podstatně vyšších nákladů nebo by bylo způsobilé vyvolat podstatné technické potíže. ${ }^{82}$ Někteří autoři ${ }^{83}$ se zamýšlejí nad tím, zda k nesplnění podmínky dle $\S 63$ odst. 4 ZZVZ stačí záměr zadavatele omezit hospodářskou soutěž bez ohledu na to, zda hospodářskou soutěž skutečně omezil/vyloučil. Jazykovým výkladem dospějeme k závěru, že pouhý záměr je pro nesplnění této podmínky dostatečný, nebot dané ustanovení používá spojení „s cílem vyloučit“. Jasné zodpovězení této otázky však pro právní praxi není podstatné, nebot toto ustanovení obsahuje ještě druhou, kumulativní, podmínku - že nelze využít jiného postupu. Lze si jen těžko představit situaci, kdy by hospodářská soutěž nebyla fakticky omezena a přitom nešlo využít jiného zadávacího řízení dle ZZVZ.

Jak uvádí důvodová zpráva k ZZVZ: „Použití tohoto ř́zení by mělo být omezeno pouze na př́pady, kdy bud' uveřejnění není možné z mimořádně naléhavých důvodů, které veřejný zadavatel nemohl předvídat a které mu nelze přičitat, nebo pokud je již od začátku jasné, že by uveřejnění nepřineslo větší hospodářskou soutěž nebo lepší výsledky, především v př́padech, kdy objektivně existuje pouze jeden dodavatel, který může veřejnou zakázku splnit. K použití jednacího řízení bez uveřejnění může opravňovat jen situace objektivní výlučnosti, situace výlučnosti tak nemůže být vytvořena samotným zadavatelem. “84

$\mathrm{Z}$ výše uvedeného je tak patrné, že využití JŘBU by mělo být pouze krajním řešením pro zadání veřejné zakázky, na což poukazuje i Úřad pro ochranu hospodářské soutěže ve svých rozhodnutích, ve kterých bylo nutné

82 DVOŘÁK; MACHUREK; NOVOTNÝ a kol., op. cit., s. 394.

${ }^{83} \mathrm{~K}$ tomu viz např. PODEŠVA, Vilém; SOMMER, Lukáš; VOTRUBEC, Jiří a kol. Zákon o zadávání veřejných zakázek. Komentár̆. Praha: Wolters Kluver (ČR), 2016, s. 275.

${ }^{84}$ Důvodová zpráva k zákonu č. 134/2016 Sb. o zadávání veřejných zakázek. In: Beck-online [online právní informační systém]. Nakladatelství C. H. Beck [cit. 22. 3. 2018]. 
posoudit splnění podmínek pro využití tohoto typu řízení. ${ }^{85}$ Obdobně se vyjádřil i Nejvyšší správní soud ve svém rozsudku ze dne 11. 1. 2013, č. j. 5 Afs 43/2012, když potvrdil, že JŘBU lze použít jen výjimečně, a to když „uspokojení potřeby zadavatele není nebo nebylo možné dosáhnout $v$ „klasickém“ zadávacím ř́zení, tj. soutěží o zakázku“. Nejvyšší správní soud se $\mathrm{v}$ tomto rozsudku rovněž vyjádřil $\mathrm{k}$ technickým důvodům pro použití JŘBU. Ty mohou dle Nejvyššího správního soudu spočívat např. v požadavku zadavatele na zajištění kompatibility nebo $\mathrm{v}$ technických okolnostech, pro které by plnění od jiného dodavatele vyvolalo „nepochybně vyšší náklady nebo značné riziko nefunkčnosti již poř̌zzeného plnění." Jedním ze základních aspektů JŘBU je totiž omezení hospodářské soutěže; jedná se o jediný druh zadávacího řízení, ve kterém se neuplatňuje zákonná povinnost odeslat oznámení o zahájení zadávacího řízení k uveřejnění. ${ }^{86} \mathrm{~V}$ JŘBU jsou totiž upřednostňovány jiné zájmy, než transparentnost. ${ }^{87}$ Je to právě ona povaha krajního řešení, která vedla k taxativnímu stanovení podmínek pro využití JŘBU a k jejich restriktivnímu výkladu. Stejně opodstatněným tak je i fakt, že důkazní břemeno k prokázání splnění podmínek pro použití JŘBU leží na zadavateli. ${ }^{88,89}$

Naplnění podmínek pro použití JŘBU neimplikuje nutnost použití tohoto zadávacího řízení. $\mathrm{Z}$ čistě procesního hlediska tak může zadavatel vždy zvolit i „přísnějši““ druh zadávacího řízení. U některých specifických plnění však bude JŘBU jedinou volbou, kterou bude zadavatel moci využít, zvláště pak v oblasti ICT. ${ }^{90}$

85 DVOŘÁK; MACHUREK; NOVOTNÝ a kol., op. cit., s. 388.

86 Tamtéž.

87 Rozsudek Nejvyššího správního soudu ze dne 11. 1. 2013, č. j. 5 Afs 42/2012 - 53.

88 „Ustanovení čl. 7 odst. 3 směrnice, která povolují výjimky z pravidel směřujících $k$ zajištění efektivity práv zaručených Smlouvou o ES v odvětví veřejných zakázek, musí být vykládána restriktivně a důkazní břemeno ohledně existence výjimečných podmínek odůvodňujících výjimku nese ten, kdo se jich dovolává. "Cit. z: Rozsudek Soudního dvora ze dne 14. 9. 2004, věc C385/02.

89 Odůvodnění použití JŘBU je dle § 217, odst. 2, písm. h) ZZVZ povinnou náležitostí písemné zprávy zadavatele.

90 DVOŘÁK; MACHUREK; NOVOTNÝ a kol., op. cit., s. 390. 
Při posuzování zákonného využití JŘBU se Úřad pro ochranu hospodářské soutěže řídí nejen zákonem, ale podpưrně i judikaturou a svou vlastní rozhodovací praxí. Příkladem z rozhodovací praxe Úřadu pro ochranu hospodářské soutěže může být rozhodnutí ze dne 9.6. 2014, č. j. ÚOHSS108/2009/VZ-12162/2014/521/VSt. Úřad pro ochranu hospodářské soutěže se zde zabýval zadávacím řízením navazujícím na zakázku, v níž byly vytvořeny počítačové programy a databáze. Tyto počítačové programy a databáze byly autorskými díly dle autorského zákona. Zadavatel si však nevyhradil možnost vykonávat majetková práva $\mathrm{k}$ těmto dílům (a např. zasahovat do zdrojového kódu) nebo poskytovat tato autorská díla třetím osobám. Vzhledem k takto (ne)upraveným obchodním podmínkám mohl plnění navazující na původní zakázku realizovat jen jediný dodavatel. $\mathrm{K}$ tomu Úřad pro ochranu hospodářské soutěže uvedl: „V prŕpadě, že by se zadavatel rozhodl realizovat předmětnou veřejnou zakázku bez využití již existujicích programů vytvořených $v$ rámci předchozích veřejných zakázek, jednalo by se sice o postup možný, avšak z ekonomického hlediska, značně nehospodárný a neefektivní, nebot by zadavatel pořizoval plnění, která již jednou zakoupil. $V$ takovém př́padě by tedy sice byla zajištěna hospodářská soutěž a konkurenční prostředí mezi dodavateli, ale došlo by $k$ nehospodárnému a neúčelnému vynakládání veřejných prostředků (zadavatel by platil za plnění, které již má a na něž již jednou veřejné prostředky vynaložil). “91 Úřad pro ochranu hospodářské soutěže tak $\mathrm{v}$ daném rozhodnutí přihlédl právě $\mathrm{k}$ principu $3 \mathrm{E}$ a zohlednil ekonomické hledisko situace.

Velká část rozhodnutí z rozhodovací praxe ÚOHS pak vychází z rozsudku Vrchního soudu v Olomouci ze dne 5. 11. 2002, č. j. 2 A 3/2002$75,{ }^{92} \mathrm{v}$ němž soud konstatoval, že okolnosti, které by mohly odůvodňovat postup, kdy zadavatel osloví jednoho konkrétního zájemce, nemohou vycházet se stavu, kdy si zadavatel nejprve vytvořil ony podmínky a teprve až

91 Blíže k zajištění principu 3E viz také rozsudek Nejvyššího správního soudu ze dne 5. 6 . 2008, č. j. 1 Afs 20/2008 - 152.

92 Např. rozhodnutí Úřadu pro ochranu hospodářské soutěže ze dne 18. 4. 2011, č. j. ÚOHSS448/2010/VZ-3396/2011/540/VKu nebo rozhodnutí Úřadu pro ochranu hospodářské soutěže ze dne 12. 4. 2012, č. j. ÚOHS-S364/2011/VZ-4144/2012/540/PVé. 
poté bylo právně nemožné nebo obtížné je změnit. ${ }^{93}$ Toto tvrzení však v žádném případě není možné vytrhnout z kontextu a je nutné zdůraznit, že rozsudek Vrchního soudu byl přijat za situace, kdy zadavatel postupoval s cílem vybudovat omezení. Právě $\mathrm{k}$,vytržení z kontextu“ v některých případech dochází i v argumentaci Úřadu pro ochranu hospodářské soutěže a projevuje se zde již předestřená problematičnost dříve zákonem nezakotvené úpravy, v současnosti explicitně zařazené pod § 63 odst. $4 \mathrm{ZZVZ.}{ }^{94}$ Takováto argumentace Úřadu pro ochranu hospodářské soutěže pak byla odmítnuta rozsudkem Krajského soudu v Brně ze dne 26. 4. 2012, č. j. 62 Af $61 / 2010$ - 332 a na něj navazujícím rozsudkem Nejvyššího správního soudu ze dne 11. 1. 2013, č. j. 5 Afs 42/2012 - 53. ${ }^{95}$ Nejvyšší správní soud v tomto rozsudku rovněž konstatoval, že je třeba „velmi pečlivě vážit, zda postup zadavatele je skutečně zaviněný, či pouze nešikovný“.

Určité právní omezení, např. formou licenčního ujednání, které způsobuje lock-in efekt, nebot’ na dané plnění může dle tohoto ujednání navázat pouze původní dodavatel, automaticky nevede k porušení ZZVZ. Každé jednání je totiž třeba hodnotit s přihlédnutím k principu 3E. Situaci objektivní nemožnosti plnění jiným zadavatelem je navíc třeba zkoumat k okamžiku zahájení JŘBU. ${ }^{96}$ Zadavatel v daném případě nemusel vědět,

${ }^{93}$ Při aplikaci tohoto rozsudku je třeba zmínit, že se nevztahuje ani k ZZVZ, ani k zákonu č. 137/2006 Sb., ale k zákonu č. 199/1994 Sb.

94 Srov. např. rozhodnutí Úřadu pro ochranu hospodářské soutěže ze dne 23. 5. 2014, č. j. ÚOHS-S604/2013/VZ-10977/2014/522/PLy s rozhodnutím Úřadu pro ochranu hospodářské soutěže ze dne 15. 10. 2009, č. j. ÚOHS-S109/2009/VZ12164/2009/510/Hod.

95 Nejvyšší správní soud v daném rozsudku uvedl, že: „Ochrana výhradních práv připadá $v$ úvahu zejména $v$ situaci, $k d y$ zadavatel získal $v$ minulosti licenční oprávnění, které je nezbytné pro pořízení dalšího plnění, a dodavatel nemá vůli udělit autorskoprávní nebo jinou licenci jiné osobě, která by plnění mohla zadavateli poskytnout. Rovněž technické důvody, které má cit. ustanovení na mysli, mohou spočivat např. v požadavku zadavatele na zajištění kompatibility, $v$ požadavku odůvodněném také technickými okolnostmi, pro které by plnění od jiného dodavatele vyvolalo nepochybně vyšši náklady nebo značné riziko nefunkčnosti již poř̌zeného plnění (zde informačního systému). Důvodem pro aplikaci tohoto ustanovení je skutečný a prokazatelný stav technické neslučitelnosti či provozních problémů, které by vznikly z důvodu změny dodavatele. Nutno konstatovat, že uvedené je typické právě mimo jiné i pro oblast informačních technologií. Zakázku, o kterou se $v$ př́padě žalobce jednalo, lze dle názoru Nejvyššího správního soudu považovat za specializovanou veřejnou zakázku, u níz lze postup, který uplatnil žalobce, shledat opodstatněným."

96 PODEŠVA; SOMMER; VOTRUBEC a kol., op. cit., s. 273. 
zda bude v budoucnu nutné zasahovat do zdrojového kódu (či provádět zásahy obdobného charakteru), a tedy nemusel rozumně očekávat, že nastane potřeba k povolení rozvoje softwaru pomocí třetí osoby či širšího licenčního oprávnění. Zakázka na plnění s takto rozšířenými právy zadavatele by byla nepochybně mnohonásobně dražší a její ekonomičnost by závisela právě na tom, zda v budoucnu potřeba úpravy kódu/rozvoje softwaru třetí stranou nastane. Logickou se zde pak jeví volba navazující veřejné zakázky až v době vyvstání takové potřeby a využití JŘBU. Byṫ Úřad pro ochranu hospodářské soutěže při posuzování oprávněnosti užití JŘBU často zdi̊razňuje právě aspekt hospodářské soutěže, ${ }^{97}$ nemůžeme zapomínat na princip 3E a na hodnocení toho, zda uzamčení nastalo cíleným postupem zadavatele, či nikoli. Bylo by totiž nesmyslné nutit veřejné zadavatele nést náklady na vyhrazení širokého spektra práv k danému plnění bez dalšího zohlednění daného případu. Např. v případě operačního systému Windows společnosti Microsoft by výhrada takovýchto práv byla ne-li nemožná, tak zajisté neuvěřitelně nákladná. Právě takovýto plošný přístup by ve svém důsledku vedl $\mathrm{k}$ rozporu s principem $3 \mathrm{E}$.

Zajímavé pak je, jak se k problematice poskytování zdrojových kódu staví ostatní státy. Např. Lotyšsko již v roce 1995 zavedlo povinnost poskytnout zdrojové kódy pro všechny ICT veřejné zakázky. ${ }^{98}$ Obdobným směrem se v roce 2016 vydalo i Bulharsko. ${ }^{99}$

$\mathrm{Na}$ tomto místě je vhodné zdůraznit, že ve světle zásady legitimního očekávání, zadavatel, který využil JŘBU a v okamžiku jeho využití objektivně splňoval zákonné podmínky pro daný postup, nemůže být za využití tohoto druhu řízení sankcionován, vyvstane-li při realizaci (nebo dokonce po ní) možnost realizovat zakázku i jinak. ${ }^{100}$

97 Např. v rozhodnutí ÚOHS ze dne 23. 5. 2014, č.j. ÚOHS-S604/2013/VZ10977/2014/522/PLy.

98 CHÝLE, Josef. Jaké otázky si klást v IT veřejných zakázkách před zahájením migrace dat a problematika vendor lock-in. Zakázkové právo v oblasti ICT a další aktuální témata - Informační list [online]. 2017, č. 1, s. 22 [cit. 4. 1. 2018].

99 BOZHANOV, Bozhidar. Bulgaria Got a Law Requiring Open Source. The Policy. [online] Medium, publikováno 4. 6. 2016 [cit. 4. 1. 2018]. 


\section{VENDOR LOCK-IN PŘI MIGRACI DAT}

Lock-in, jak již bylo nastíněno výše, se často vyskytuje při migraci dat, kdy je dodavatel pro zadavatele zpracovatelem těchto dat. ${ }^{101}$ Vzhledem $\mathrm{k}$ tomu, jak cenným artiklem data $v$ dnešní době jsou, je nutné tomuto tématu věnovat zvýšenou pozornost. V případě, že smluvní vztah mezi zadavatelem a dodavatelem není kvalitně nastaven, může se totiž stát, že zpracovávaná data, o která by měl zadavatel zájem, nebude bez dodavatele po skončení smluvního vztahu schopen sám zpracovávat - přenést je do své sféry (např. cloudu), ${ }^{102}$ uspořádat je do databází nebo je ke zpracování předat jinému dodavateli.

Při správě dat je tedy třeba počítat s tím, že v budoucnu může být nutná jejich migrace. Tuto migraci je třeba řádně smluvně ošetřit, a to včetně té předčasné - např. z důvodu předčasného jednostranného ukončení smlouvy pro nespokojenost zadavatele.

Portabilitu dat je možné maximalizovat za použití standardi̊ jako např. The Open Data Element Framework („O-DEF“) ${ }^{103}$ a Cloud Data Management Inferference („CDMI“). ${ }^{104}$ Zadavatel by měl rovněž zvážit multi-cloudovou strategii a dále zhodnotit, zvláště pak pro cloud-computing aplikací, možnost použití DevOps nástrojů a procesů. ${ }^{105}$ Je rovněž důležité vyřešit otázku vlastnictví dat, ${ }^{106}$ nebot je známo, že např. v oblasti cloudových služeb je to provozovatel cloudu, kdo je ve výchozím stavu často vlastníkem

${ }^{100}$ ČECH, Martin. Otázky zákonnosti postupu zadavatele při zadávání ICT veřejných zakázek $\mathrm{v}$ př́ipadě pořízení komplexního informačního systému v soutěži o návrh. EPRAVO.CZ [online]. EPRAVO.CZ, a.s., publikováno 4. 1. 2016 [cit. 4. 1. 2018].

${ }^{101} \mathrm{~K}$ tomu viz např. OPARA-MARTINS, Justice; SAHANDI, Reza; TIAN, Feng. Critical analysis of vendor lock-in and its impact on cloud computing migration: a business perspective. Journal of Cloud Computing [Online]. 2016 [cit. 4. 1. 2018].

${ }^{102}$ Blíže k modelům cloud computingu viz BENTO, Alberto, AGGARWAL, Anil. Cloud Computing Service and Deployment Models. Hershey: Business Science Reference, 2013, s. 213.

${ }^{103}$ Blíže k O-DEF viz např. webové stránky O-DEF [online]. The Open Group [cit. 6. 1. 2018].

${ }^{104}$ Blíže k CDMI viz např. webové stránky Cloud Data Management Interface (CDMI) [online]. SIA [cit. 6. 1. 2018].

${ }^{105}$ CHAN, Mike. 6 things you can do to avoid cloud vendor lock-in. ThornTech.com [online]. Thorn Technologies LLC, publikováno 18. 9.2017 [cit. 6. 1. 2018].

${ }^{106}$ Blíže k problematice vlastnictví dat POLČÁK, Radim. Informace a data v právu. Revue pro právo a technologie [Online]. 2016, č. 13, s. 82-85. [cit. 8. 1. 2018]. 
uložených údajů. ${ }^{107}$ Vlastnictví dat je tak třeba ošetřit zvláště pro období po ukončení smluvního vztahu. Obchodní podmínky by měly být nastaveny zejména tak, aby byla migrace dat zaručena $\mathrm{v}$ požadovaném rozsahu, formátu a čase, ${ }^{108}$ a to nejen směrem $\mathrm{k}$ zadavateli, ale př́ípadně $\mathrm{i} k$ dalšímu správci dat, který bude zadavatelem určen. Zadavatel pro sestavení smluvních podmínek může využít rovněž předběžné tržní konzultace $s$ odborníky a dodavateli dle $\S 33$ ZZVZ. Vhodné může být také zařazení výše nákladů, které vzniknou zadavateli v důsledku migrace dat, jakožto dílčího hodnotícího kritéria v rámci hodnocení ekonomické výhodnosti. ${ }^{109}$

$\mathrm{V}$ př́padě, kdy dodavatel zpracovává pro zadavatele osobní údaje (zadavatel vystupuje $\mathrm{v}$ roli správce osobních údajů a dodavatel $\mathrm{v}$ roli zpracovatele osobních údajů), je do obchodních podmínek (smlouvy) třeba zařadit všechny náležitosti dle GDPR, ${ }^{110}$ přičemž uzavření takové smlouvy je primárně povinností správce. ${ }^{111} \mathrm{I}$ v situacích, kdy dodavatel pro zadavatele nezpracovává osobní údaje, ale jiná data, lze pro předejití lock-inu doporučit do smlouvy zařadit ustanovení obdobná těm v čl. 28 GDPR, zvláště pak: povinnost zpracování dat pouze na základě doložených pokynů správce, zajištění řádného zabezpečení zpracování, zohlednění povahy zpracování, povinnost v souladu s rozhodnutím správce všechny osobní údaje bud' vymazat, nebo je správci vrátit a vymazat existující kopie. Lze rovněž doporučit zakotvení povinnosti umožnit zadavateli audity, včetně inspekcí, prováděných zadavatelem nebo zadavatelem pověřeným auditorem.

Kvalitně zpracované obchodní podmínky je třeba zdůraznit především proto, že při jejich absenci lze migraci dat za pomocí právních předpisů řešit jen $\mathrm{v}$ omezeném počtu př́padů. Těmito případy jsou migrace osobních údajů dle GDPR, povinná migrace dat dle zákona č. 181/2014 Sb., o

${ }^{107}$ VÉVODA, Petr. Data obsažená v IT systémech, jejich vlastnictví a zakázkové právo. Zakázkové právo v oblasti ICT a dalši aktuální témata - Informační list [online]. 2017, č. 1, s. 17 [cit. 8. 1. 2018].

${ }^{108}$ SOCHOR, Miloš. Právní aspekty ochrany osobních údajů v rámci cloudových služeb. PRÁVNÍ PROSTOR.CZ [online]. ATLAS consulting spol. s r.o., publikováno 27. 2. 2017 [cit. 10. 1. 2018].

${ }^{109}$ VÉVODA, op. cit., str. 18.

${ }^{110}$ Čl. 28 odst. 3 GDPR.

${ }^{111}$ Použitelnost GDPR je stanovena na 25. 5. 2018. 
kybernetické bezpečnosti, a dále povinná migrace dat dle zákona č. 365/2000 Sb., o informačních systémech veřejné správy.

GDPR ukládá správcům osobních údajů povinnost uzavřít se zpracovateli smlouvu o zpracování osobních údajů obsahující ustanovení, že zpracovatel osobních údajů v souladu s rozhodnutím správce všechny osobní údaje bud' vymaže, nebo je vrátí správci po ukončení poskytování služeb spojených se zpracováním, a vymaže existující kopie. ${ }^{112}$ Neuzavření takovéto smlouvy podléhá dle GDPR správním sankcím. ${ }^{113}$ GDPR správci právo migrovat osobní údaje nepřiznává, aniž by bylo smluvně upraveno. GDPR navíc $\mathrm{v}$ daném případě neupravuje to, $\mathrm{v}$ jakém formátu mají být osobní údaje předány. Mưže se tak teoreticky stát, že osobní údaje budou předány ve formátu, se kterým správce nebude schopen dále nakládat dle svých potřeb.

V případě, kdy mezi správcem a zpracovatelem osobních údajů chybí smluvní úprava zajištující předání osobních údajů v adekvátním formátu a zpracovatel tak odmítá učinit, jeví se jako možné, nevylučují-li to jiné skutečnosti vč. dalších smluvních podmínek, využít toho, že dle čl. 28 odst. 3 písm. a) zpracovává zpracovatel osobní údaje pouze na základě doložených pokynů správce. K tomu je opět třeba zakotvení této povinnosti do smlouvy o zpracování osobních údajů, jak ve svém čl. 28 ukládá GDPR. Správce tak obecně může zpracovateli udělit pokyn ke zpracování osobních údajů v daném formátu a k jejich následnému předání správci. Neumožňuje-li toto vztah správce a zpracovatele $\mathrm{z}$ jakéhokoli do̊vodu a zpracovatel takovéto předání odmítá učinit, může se správce pokusit uplatnit velmi složitou konstrukci využívající v GDPR stanovené právo na přenositelnost osobních údajů. V této konstrukci by správce vystupoval jako zmocněný zástupce subjektů údajů využívajících své právo na přenositelnost osobních údajů. $^{114}$

S právem na ochranu osobních údajů je neodmyslitelně spjato i ústavně zaručené právo na ochranu soukromého a rodinného života. ${ }^{115}$ Cílem tohoto práva je „zamezit jakýmkoli škodlivým zásahům do soukromí osob, at’ již ze

\footnotetext{
${ }^{112}$ Čl. 28 odst. 3 písm. g) GDPR.

${ }^{113}$ Správní sankce jsou v GDPR upraveny v čl. 83 a 84.
} 
strany soukromých subjektů nebo veřejné moci“. ${ }^{116}$ Vzhledem k důležitosti, kterou ochraně osobních údajů a soukromého a rodinného života přiznávají nejen právní předpisy síly zákona, ale i ústavní pořádek a evropské právo, a kterou Úřad pro ochranu osobních údajů reflektuje ve svých rozhodnutích, je možné usuzovat, že by na veřejné dodavatele měly být kladeny vysoké nároky při dodržování jejich povinností spojených s ochranou osobních údajů. $\mathrm{V}$ případě porušení by tak měli být vystaveni hrozbě sankcí dle čl. 83 odst. 4 písm. a) GDPR - do výše 10000000 EUR, nebo jedná-li se o podnik, až do výše $2 \%$ celkového ročního obratu celosvětově za předchozí finanční rok, podle toho, která hodnota je vyšší. Právě tato hrozící pokuta by mohla být pro některé dodavatele dostatečně motivující a mohla by tak, vlastně nepřímo, pomoci předcházet proprietárnímu uzamčení, byt’ toto nebylo primárním cílem přijetí GDPR. ${ }^{117}$

Návrh nového (adaptačního) zákona o zpracování osobních údajů však na základě čl. 83 odst. 7 GDPR - ve svém $\S 60$ odst. 5 počítá pro orgány ve-

${ }^{114}$ Důležité je zdůraznit, že se nejedná o právo správce, nýbrž o právo subjektu údajů. Subjekt údajů má dle čl. 20 GDPR právo získat osobní údaje, které se ho týkají - jež správci poskytl - ve strukturovaném, běžně používaném a strojově čitelném formátu. Toto právo je možné uplatnit $\mathrm{v}$ př́padě, kdy subjekt údajů poskytl své osobní údaje na základě souhlasu, nebo pokud je zpracování nezbytné za účelem plnění smlouvy; a zpracování se provádí automatizovaně. Zároveň má subjekt údajů právo na to, aby byly osobní údaje předány jedním správcem přímo správci druhému. Teoreticky může být zajištění plnění převedeno $\mathrm{z}$ jednoho zadavatele na jiného (např̀. $\mathrm{v}$ rámci ministerstev, jak bylo nastíněno výše $\mathrm{v}$ části pojednávající o NAKIT a SPCSS). Následně by pak mohly všechny subjekty údajů požádat původního správce o přenesení svých osobních údajů ve strukturovaném, běžně používaném a čitelném formátu ke správci novému (tak může být učiněno skrze původního správce za pomocí institutu zastoupení). Zpracovatel by pak měl mít povinnost, byla-li mezi ním a správcem uzavřena ráaná smlouva dle čl. 28 GPDR, být správci nápomocen prostřednictvím vhodných technických a organizačních opatření ke splnění správcovy povinnosti reagovat na žádost o výkon práv subjektu údajů.

${ }^{115}$ Čl. 10 odst. 2 Listiny základních práv a svobod.

${ }^{116}$ Rozhodnutí Úřadu pro ochranu osobních údajů ze dne 16. 11. 2017, č. j. UOOU-08211/1713 nebo př́kaz Úřadu pro ochranu osobních údajů ze dne 17. 10. 2017, č. j. UOOU09611/17-8.

${ }^{117}$ Dle odst. 2 recitálu GDPR je cílem GDPR přispět $\mathrm{k}$ dotvoření prostoru svobody, bezpečnosti a práva a hospodářské unie, $\mathrm{k}$ hospodářskému a sociálnímu pokroku, $\mathrm{k}$ posílení a sblížení ekonomik v rámci vnitřního trhu a k dobrým životním podmínkám fyzických osob. 
řejné moci a veřejné subjekty s pokutou pouze do výše $10000000 \mathrm{Kčc},{ }^{118}$ což může motivaci k uzavírání řádných smluv značně limitovat.

Zároveň je možné usuzovat, že by $\mathrm{k}$ ochraně osobních údajů přispělo, kdyby nový zákon o zpracování osobních údajů obsahoval ustanovení stanovující řešení situace, kdy řádná smlouva o zpracování osobních údajů dle čl. 28 GDPR není uzavřena, a to tak, že by zpracovatelům stanovoval povinnost osobní údaje správci na správcovu žádost (s nárokem na úhradu účelně vynaložených nákladů) předat, ideálně pak právě ve strukturovaném, běžně používaném a strojově čitelném formátu - analogicky $\mathrm{k}$ vyhovění žádosti subjektu údajů na jejich přenositelnost.

Úřad pro ochranu osobních údajů $\mathrm{v}$ minulosti uložil pokutu za ztrátu/nepořízení osobních údajů, konkrétně zdravotnické dokumentace. ${ }^{119}$ Teoretickou otázkou tak zůstává, zda Úřad pro ochranu osobních údajů $\mathrm{v}$ návaznosti na novou právní úpravu $\mathrm{v}$ budoucnu nepřikročí v některém $\mathrm{z}$ prrípadů vendor lock-inu, např. u pořízeného informačního systému pro nemocnice, $\mathrm{u}$ kterého $\mathrm{z}$ právních a administrativních důvodů není dočasně dořešen pokračující provoz, $\mathrm{k}$ uložení opatření $\mathrm{k}$ nápravě, ${ }^{120}$ které by zpracovateli např. ukládalo povinnost zpracování těchto dat. Takovéto zpracování by totiž mohlo být $\mathrm{v}$ zájmu subjektů údajů. Právě subjekty údajů právní úprava zpracování osobních údajů chrání především. ${ }^{121}$ Nutnost ochrany osobních údajů před jejich ztrátou je patrná právě ve zdravotnické dokumentaci obsahující zvláštní kategorie osobních údajů. ${ }^{122}$

\footnotetext{
${ }^{118}$ Sněmovní tisk 138 (8. volební období), návrh zákona o zpracování osobních údajů [online]. Úřad vlády České republiky [cit. 28. 3. 2018].

${ }^{119}$ Př́íkaz Úřadu pro ochranu osobních údajů ze dne 21. záŕí 2016, č. j. UOOU-08449/16-3.

${ }^{120}$ V současné době účinný zákon č. 121/2000 Sb. ani Sněmovní tisk 138 (8. volební období), návrh zákona o zpracování osobních údajů [online]. Úřad vlády České republiky [cit. 28. 3. 2018] neposkytují výčet opatření $\mathrm{k}$ nápravě (dle terminologie návrhu zákona o zpracování osobních údajů opatření $k$ odstranění nedostatků), které může Úřad pro ochranu osobních údajů uložit.

${ }^{121}$ NULÍČEK, Michal; DONÁT, Josef; NONNEMANN František a kol. Obecné nařizení o ochraně osobních údajů (GDPR): Praktický komentár. In: ASPI [právní informační systém]. Wolters Kluwer [cit. 22. 3. 2018].

${ }^{122}$ Zvláštní kategorie osobních údajů je pojem užívaný GDPR. Tento pojem je ekvivalentním k pojmu citlivé osobní údaje užívaným v současné době účinným zákonem č. 101/2000Sb.
} 
Vedle migrace osobních údajů může zadavatel přistoupit i k migraci blíže nespecifikovaných dat. Tu může za určitých okolností, chce-li využít zákonné instituty, provést dle ustanovení zákona o kybernetické bezpečnosti. Zákon o kybernetické bezpečnosti byl novelizován zákonem č. 104/2017 Sb., účinným od 1 . července 2017 , a právě na základě této novely je možno nově přistoupit $\mathrm{k}$ mandatorní migraci. Zákon o kybernetické bezpečnosti totiž nyní umožňuje správci informačního systému kritické informační infrastruktury, komunikačního systému kritické informační infrastruktury nebo významného informačního systému pověřit provozem tohoto systému jiný orgán nebo osobu - provozovatele, pokud to jiný zákon nevylučuje. ${ }^{123}$

Provozovatel takto taxativně vymezených systémů má pak povinnost, S nárokem na úhradu účelně vynaložených nákladů, ${ }^{124}$ správci na jeho vyžádání předat data, vč. provozních údajů a informací, která má k dispozici v souvislosti s provozováním tohoto systému a které jsou nezbytné pro případný další provoz tohoto systému nebo jeho jiné využití. ${ }^{125}$ Provozovatel má dle zákona rovněž povinnost bezpečně zlikvidovat veškeré kopie těchto dat ve svém digitálním prostředí. ${ }^{126}$ Povinnost migrovat data může být rovněž uložena, na návrh správce, rozhodnutím Úřadu pro kybernetickou a informační bezpečnost, hrozí-li kybernetický bezpečnostní incident. ${ }^{127}$

Novela je reakcí na stav, kdy správce kvůli neshodám s provozovatelem informačního systému nemá přístup $\mathrm{k}$ datům nutným pro výkon své pravomoci. ${ }^{128}$ Novela tak správcům přináší nový, zajisté potřebný nástroj, jak zajistit bezproblémový chod vybraných informačních systémů. Zároveň představuje řešení proprietárních uzamčení bránících dodavatelům vybrat lepšího dodavatele. ${ }^{129}$ Je však třeba zdo̊raznit, že ani zákon o kybernetické bez-

\footnotetext{
${ }^{123}$ § 6a odst. 1 zákona č. 181/2014 Sb.

${ }^{124} \S$ 6a odst. 4 zákona č. 181/2014 Sb.

${ }^{125} \S$ 6a odst. 2 zákona č. 181/2014 Sb.

${ }^{126}$ § 6a odst. 3 zákona č. 181/2014 Sb.

127 § 15a odst. 1 zákona č. 181/2014 Sb.

${ }^{128}$ Důvodová zpráva k zákonu č. 104/2017 Sb. In: Beck-online [online právní informační sys tém]. Nakladatelství C. H. Beck [cit. 22. 3. 2018].

129 Tamtéž.
} 
pečnosti neposkytuje nástroj pro řešení migrace dat ve vztahu ke všem informačním systémům, nýbrž jen $\mathrm{k}$ těm $\mathrm{v}$ zákoně vymezeným.

Stejná novela zároveň novelizuje i zákon o informačních systémech veřejné správy. Novelizovaný zákon pak ve svém § 9e ukládá provozovateli informačního systému veřejné správy povinnost bezodkladně na vyžádání správce informačního systému veřejné správy předat data a provozní údaje týkající se tohoto systému. Po ukončení provozování informačního systému je pak provozovateli rovněž dána povinnost předat data správci a zároveň vymazat kopie těchto dat a provozních údajů. Provozovatel má i zde nárok na úhradu účelně vynaložených nákladů spojených s migrací dat. Novelizovaný zákon o informačních systémech veřejné správy opět pozitivně přispívá $\mathrm{k}$ řešení přenosu dat. Jeho působnost je však z logických důvodů rovněž limitována a ani $\mathrm{v}$ tomto př́padě se tedy nejedná o univerzální řešení pro veškeré správce, ani pro veškeré veřejné zadavatele. Vzhledem $\mathrm{k}$ charakteru činností veřejných zadavatelů lze však předpokládat, že velká část jejich systémů bude vyhodnocena jako systémy veřejné správy, ${ }^{130}$ a proto lze $\mathrm{v}$ současné době tento zákon považovat za pravděpodobně nejúčinnější zákonný nástroj pro řešení proprietárního uzamčení $\mathrm{v}$ oblasti správy dat veřejných zadavatelů.

\section{VENDOR LOCK-IN Z DU゚VODU VYSOKÝCH NÁKLADŮ NA ZMĚNU}

Switching costs lock-in je uzamčením, jemuž by zadavatelé měli předcházet primárně. Je totiž jejich odpovědností, aby bylo zajištěno využívání veřejných prostředků $\mathrm{v}$ souladu s principem $3 \mathrm{E}$. Hospodárnost, efektivnost a účelovost nakládání $s$ veřejnými prostředky označuje Fričová dokonce jako ultimátní účel ZZVZ. ${ }^{131} \mathrm{Na}$ druhou stranu lze často pozorovat zájem dodavatelů na vytvoření switching costs lock-inu, nebơ jsou to právě dodava-

\footnotetext{
${ }^{130}$ Informační systém veřejné správy je definován v § 2 písm. b) zákona č. 365/2000 Sb.

${ }^{131}$ FRIČOVÁ, Vítezslava. Shrnutí judikatury k problematice zadávání veřejných zakázek v oblasti IT v jednacím řízení bez uveřejnění. Zakázkové právo $v$ oblasti ICT a další aktuální témata - Informační list [online]. 2017, č. 1, s. 34 [cit. 4. 1. 2018].
} 
telé, komu toto uzamčení ekonomicky svědčí. ${ }^{132}$ Zároveň se jedná o jednu z nejnáročnějších forem proprietárního uzamčení ve smyslu možnosti jejího řešení ex post, ${ }^{133}$ vzhledem $\mathrm{k}$ tomu, že vysoké náklady na změnu již samy o sobě většinou představují důsledek/řrešení jiné závislosti zadavatele na dodavateli. Hledáme tak vlastně ,řešení jiného řešeni“. V oblasti ICT jsou náklady na změnu často obtížně vyčíslitelné, nebot jsou kromě pořizovacích nákladů představovány i náklady na přeškolení pracovníků, ušlým ziskem za dobu přechodu na novou technologii, ušlým ziskem způsobeným počátečním snížením produktivity zaměstnanců, znehodnocením původních investic - včetně těch souvisejících, a případnými dalšími skrytými náklady.

Obvyklým technologickým důvodem vzniku tohoto druhu uzamčení je inkompatibilita pořizovaného plnění s plněním, které by mělo být rozvíjeno / na něž by mělo být navázáno. Za právní důvod vzniku lze označit př̀devším nevhodně definovaný předmět veřejné zakázku a nedostatečně upravené obchodní podmínky. Typickým nedostatkem obchodních podmínek je nedostatečné vymínění práv ze strany zadavatele. Smlouva pak často neumožňuje zásah do stávajícího řešení ze strany veřejného zadavatele nebo zadavateli nedává právo konverze řešení (nebo v něm obsažených dat) na jiný, zadavatelem $v$ době změny preferovaný, formát nebo standard. Vysoké náklady na změnu tak zabraňují skutečnému výběru a flexibilitě. ${ }^{134}$

Switching costs lock-in se projevuje primárně v situaci, kdy se zadavatel rozhoduje, zda pořídí nové řešení, nebo zda bude rozvíjet řešení současné, a pokud se rozhodne pro rozvoj řešení současného, pak také o tom, kdo toto řešení bude rozvíjet - zda současný dodavatel, nebo někdo jiný.

Náklady na změnu jsou přirozeným jevem téměř u každého přechodu na nové řešení. Problém nastává, když tyto náklady začínají být neúměrně velké. Představme si řešení, které zadavatel v minulosti pořídil, a nyní potřebuje jeho další rozvoj - např. software a rozvoj jeho zdrojového kódu.

\footnotetext{
${ }^{132}$ Srov. AMARSY, Nabila. Switching Costs: 6 Ways To Lock Customers Into Your Ecosystem. Strategyzer.com [online]. Strategyzer.com, publikováno 27. 7. 2015 [cit. 4. 1. 2018].

133 Srov. SEROTER, op. cit.

${ }^{134}$ SHAH; KESAN; KENNIS, op. cit. s. 7.
} 
Zadavatel sleduje $100 \%$ využití svých „výrobních“ zdrojů. Stávající software zadavateli umožňuje využití výrobních zdrojů na $70 \%$. Rozvoj softwaru je z důvodů práv duševního vlastnictví nebo např. jedinečného knowhow nutného $\mathrm{k}$ úpravě zdrojového kódu možný pouze stávajícím dodavatelem a za využití JŘBU. Vedle rozvoje stávajícího řešení však zadavatel musí zvážit i možnost pořízení zcela nového software zrealizovaného tzv. na zelené louce, který by zadavatelovým požadavkům opět vyhovoval na $100 \%$. Počáteční investice na pořízení nového software by ve většině případů byla pravděpodobně mnohonásobně vyšší než pouhý rozvoj stávajícího řešení. Rozhodovat se však pouze na základě počáteční investice by bylo krátkozraké, nebot je třeba zhodnotit i ostatní aspekty pro výběr té nejvhodnější možnosti, vč. potřeby rozvoje řešení v budoucnu, která pravděpodobně vyvstane, a u stávajícího řešení bude pravděpodobně proveditelná opět pouze stávajícím dodavatelem. Při zadávání zakázky na nový software může být potřeba dalšího rozvoje lépe ošetřena, takže rozvoj řešení bude zajištěn $\mathrm{i}$ $\mathrm{v}$ řádném soutěžním prostředí a může být i levnější. Zadavatel by tedy měl u rozvoje stávajícího řešení sledovat i) počáteční investici na rozvoj řešení, ii) cenu provozu software a iii) očekávané výdaje pro rozvoj softwaru v budoucnu. Tuto finanční zátěž by měl zadavatel následně porovnat se zátěží představovanou i) počáteční investicí na pořízení nového řešení, ii) cenou provozu softwaru, iii) očekávanými výdaji na rozvoj tohoto softwaru a iv) dalšími náklady na změnu spojenými s přechodem na nový systém.

Je třeba upozornit na možnost toho, že se zadávacího řízení na novou zakázku „na zelené louce“ zúčastní i dodavatel stávajícího řešení. Tento dodavatel však může mít u zadavatele implementovánu řadu funkcionalit. To mu v účasti v zadávacím řízení poskytuje značnou výhodu, nebot do své nabídkové ceny nemusí zahrnout náklady na implementaci (zahrne typicky licenční poplatky, cenu za podporu, rozvoj ad.). Existuje však riziko, že si daný dodavatel za implementaci zaplatit (tř̌eba jen částečně) nechá, byt na ni ve skutečnosti nemusí mít žádné náklady. Tento dodavatel i přesto může se svou nabídkou uspět, nebot je jeho soutěžní výhoda značná. Zadavatel tak sice zajistí hospodářskou soutěž, ale vynaloží zbytečné náklady, které by nevynakládal, kdyby využil JŘBU. 
Switching costs lock-in jakožto uzamčení, které z ekonomických důvodů odrazuje zadavatele od změny řešení, však sám o sobě není důvodem pro využití JŘBU. Jak bylo uvedeno v kapitole 6 Jednací řżení bez uveřejnění $v$ aplikační praxi, ZZVZ poskytuje taxativní výčet podmínek, které umožňují $\mathrm{k}$ JŘBU přistoupit, přičemž vysoké náklady na změnu nelze samy o sobě považovat za dostatečné pro naplnění některé z podmínek. Vysoké náklady na změnu představují pouze prvotní indikátor toho, že by některá z podmínek daných § 63 odst. 3 ZZVZ mohla být naplněna.

Typickým př́kladem proprietárního uzamčení je vztah vzniklý mezi zadavatelem Hlavní město Praha a dodavatelem HAGUESS, a.s. při uzavírání série smluv souvisejících s čipovými kartami Opencard. Zadavatel Hlavní město Praha se v tomto případě stal závislým na dodavateli $\mathrm{z}$ důvodu autorských práv, resp. nevýhodných licenčních smluv, které s dodavatelem uzavřel, což následně vyústilo i v uzamčení z důvodů vysokých nákladů na změnu. Zadavatel následně nesplnil podmínky pro využití JŘBU, nebot? uzamčení svým aktivním jednáním sám vytvořil, když uzavřel smlouvu $\mathrm{s}$ nevýhodnými licenčními podmínkami. Zadavatel ale i přesto k JŘBU přistoupil a vybral tak $v$ daném případě nelegální variantu řešení této situace. $^{135}$

K využití JŘBU zadavatele pravděpodobně vedlo především to, že z krátkodobého hlediska bylo zadání zakázky na rozvoj stávajícího řešení výhodnější, než pořízení celého nového řešení za zajištění výhodnějších licenčních smluv - v takovém případě by totiž zadavatel musel jednorázově nést celou výši nákladů na změnu. ${ }^{136}$

\footnotetext{
${ }^{135}$ Rozhodnutí Nejvyššího správní soudu ze dne 12. 5. 2016, č. j. 1 As 256/2015 - 95.

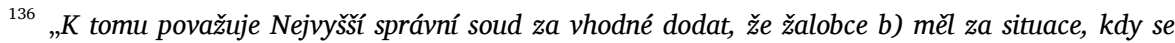
o zakázku ucházel jediný subjekt, přinejmenším dvě legální cesty. Mohl postupovat bud’ způsobem, který navrhl krajský soud, tedy zadávací ř́zení zrušit a vypsat je poté př́padně znovu $s$ určitými modifikacemi tak, aby je otevřel širšímu okruhu potenciálních uchazečů. Nebo mohl postupovat tak, jak postupoval, tedy zadávací ř́zení nezrušit a přistoupit na licenční podmínky společnosti HAGUESS, a.s. Při zvolení této varianty si však musel být vědom omezení, které pro něj z takového postupu vyplývá, tedy následné nemožnosti zadat navazující zakázky $v$ jednacím ř́zení bez uveřejnění, a podle toho dále jednat. Žalobce b) si zvolil třetí, nelegální variantu, $v$ rámci níž přistoupil na omezující licenční podmínky jediného uchazeče a zároveň následné zakázky zadával $v$ jednacím ř́zení bez uveřejnění tomuto jedinému uchazeči. Takový postup byl však v rozporu se zákonem, jak uzavřel soud výše. “ Tamtéž.
} 
Dalším příkladem proprietárního uzamčení z českého právního prostředí je např́iklad vztah mezi Ministerstvem Financí a IBM Česká republika spol. s r.o. Od roku 1992 je IBM dodavatelem pro daňový informační systém ADIS. Od té doby na rozvoj a údržbu systému neproběhlo žádné otevřené řízení a vše je řešeno $v$ rámci JŘBU, včetně implementace EET (pořizované Generálním finančním ředitelstvím) v roce $2016 .{ }^{137}$ Vybudování nové infrastruktury pro daňový systém by s sebou opět přinášelo nutnost značné počáteční investice.

Pro předcházení uzamčení z důvodů nákladů na změnu je důležité především vhodně definovat předmět veřejné zakázky a to s ohledem na dobu, na kterou je tento předmět pořizován. Důsledné definování předmětu veřejné zakázky je důležitým předtranskačním opatřením. Jeho kvalitní určení však vyžaduje kromě právních a ekonomických znalostí právě i znalost oblasti ICT, což je v praxi problém, nebot veřejní zadavatelé v současné době často nedisponují týmem, který by tyto komplexní znalosti měl. Zvláště pak v oblasti ICT můžeme sledovat trend outsourcingu. Právě v tomto případě může být vhodné zapojení externího poradce i z oblasti ICT. Dle Cockcrofta je nejlepším způsobem pro předcházení switching costs lock-in efektu uvažovat jako vývojár. ${ }^{138}$ Jsou to totiž právě vývojáři, pro koho jsou náklady na změnu obecně nejnižší. Vývojáři vyvíjí nová řešení dlouhodobě a pravidelně, a to většinou skrze menší - dílčí - úpravy stávajícího řešení. K potřebným úpravám navíc mají patřičné know-how, což značně snižuje čas strávený nad úpravou a zároveň ve většině případů i přispívá k vyšší kvalitě vyvíjeného řešení.

Základní právní možnosti předcházení proprietárnímu uzamčení byly diskutovány v kapitole 5 Právní možnosti předcházení vendor lock-inu při přípravě zadávací dokumentace a všechny tyto možnosti, nejlépe v jejich vzájemné kombinaci, lze použít rovněž jako nástroje pro předcházení tomuto

\footnotetext{
${ }^{137}$ DURAJ, Adam. Vendor lock-in in IT procurement [online]. Praha, 2017, s. 18 [cit. 25. 10. 2017]. Bakalářská práce. Karlova univerzita, Fakulta sociálních věd. Vedoucí práce Jiří SKUHROVEC.

${ }^{138}$ COCKCROFT. Adrian. Who Doesn't Like Lock-In? Battery.com. [online]. Battery Ventures, publikováno 20. 4. 2016 [cit. 24. 3. 2018].
} 
konkrétnímu uzamčení, přičemž je třeba zdůraznit možnost používání open standardi̊, open-source softwaru a modulárního plánování.

Vedle důsledného stanovení předmětu veřejné zakázky je třeba věnovat značnou pozornost i určení podmínek kvalifikace, kritérií hodnocení a náležité smluvní úpravě, jak je rovněž popsáno výše v tomto článku. Je to právě uzamčení $\mathrm{z}$ důvodu vysokých nákladů na změnu, které se dá značně redukovat za pomocí stanovení nákladů na životní cyklus, jakožto kritéria hodnocení, když budou zohledněny náklady na ukončení provozu původního řešení a přechod na řešení nové, a to alespoň ty nejvýznamnější - tedy např. následná konverze dat nebo redukce hardwaru na některý $\mathrm{z}$ běžně užitých standardů, nerozhodne-li se zadavatel pro zavedení tohoto standardu z nějakého důvodu (např. pro dodržení zásady nediskriminace) již při určování předmětu veřejné zakázky. Vhodným opatřením může být také zapojení interních ICT expertů nejen do předtransakční fáze pořizování daného řešení, ale i do jeho následného provozu, aby mohli získat patřičné know-how pro rozvoj daného systému, a tím přispět k redukci nákladů.

Dostane-li se zadavatel do proprietárního uzamčení z důvodů nákladů na změnu, měl by využít postupy $\mathrm{k}$ vyvázání se $\mathrm{z}$ takovéto závislosti. Ty vždy závisejí na konkrétních podmínkách a v návaznosti na nich pak mohou být z krátkodobého hlediska více, či méně nákladné; z dlouhodobého hlediska by však měly být obecně ekonomičtější. $\mathrm{K}$ těmto základním nástrojům patří technologické změny směrem ke standardizovaným nebo alespoň dostupnějším řešením, zahrnutí nových dodavatelů do parciálních projektů, insourcing a vedení dialogu se stávajícím dodavatelem. ${ }^{139}$

\section{ZÁVĚR}

V první kapitole tohoto článku byly popsány formy uzamčení a důvody jejich vzniku. Jako důvody vzniku tohoto uzamčení byly identifikovány př́činy technologické, ekonomické, smíšené a právní. Za jediný zcela právní důvod vzniku vendor lock-inu byla shledána práva duševního vlastnictví. V oblasti veřejného zadávání byl jako nejvýznamnější lock-in určen vendor

${ }^{139}$ SKUHROVEC, op. cit., s. 19. 
lock-in z důvodu vysokých nákladů na změnu, nebot’ přímo ovlivňuje rozpočty veřejných zadavatelů a je tak $\mathrm{v}$ rozporu s principem 3E.

V druhé kapitole byly popsány specifika oblasti ICT veřejných zakázek ve vztahu k vendor lock-inu. Jako tato specifika byla mimo jiné popsána: pořizování technologie s výhledem na několik let, její rychlý vývoj, vysoké znalostní nároky na veřejného zadavatele $\mathrm{v}$ mnoha různých odvětvích a $\mathrm{v}$ případě softwaru také nehmatatelnost výstupu.

Ve třetí kapitole byly popsány přímé a nepřímé projevy proprietárního uzamčení. Jakožto nepřímý projev lock-inu bylo určeno i in-house zadávání. Na tomto místě pak byl nalezen nedostatek v současné právní úpravě. Ta v režimu in-house znemožňuje přímé využití státního podniku ovládaného jedním ministerstvem jinou organizační složkou státu na stejné horizontální úrovni. To nekoresponduje s principem 3E. V návaznosti na toto zjištění byl v článku formulován návrh na odstranění daného nedostatku novelizací ZZVZ. V této části článku byly diskutovány také jevy spojené s tržní silou a technologickou dominancí. Dále bylo upozorněno na formální indikátory budování lock-inu. I tyto skutečnosti totiž mohou být projevem tvorby proprietárního uzamčení.

Čtvrtá kapitola tohoto článku byla věnována právním možnostem předcházení lock-inu. Jako zásadní bylo identifikováno kvalitní definování předmětu veřejné zakázky. Při definování předmětu veřejné zakázky je třeba zhodnotit především dobu, na kterou bude řešení pořizováno. Dále je třeba zajistit kompatibilitu jednotlivých řešení, např. za použití open source softwaru nebo open standardů. Jako zásadní nástroj předcházení lock-inu bylo rovněž popsáno i vymezení adekvátního spektra práv zadavatele $\mathrm{k}$ předmětu plnění. Jako další právní nástroje pro předejití proprietárnímu uzamčení byly určeny řádně nastavené podmínky kvalifikace a kritéria hodnocení. Dalším vhodným kritériem hodnocení v oblasti ICT bylo shledáno kritérium nákladů na životní cyklus.

Pátá kapitola je zaměřena na jednací řízení bez uveřejnění a podmínky jeho využití. Byl identifikován nekonzistentní přístup k zaviněné exkluzivitě ze strany Úřadu pro ochranu hospodářské soutěže, kdy je někdy přihlíženo k principu 3E, jindy je však plošně pokutováno využití JŘBU na zákla- 
dě uzamčení plynoucího ze zadavatelem uzavřených licenčních podmínek. V návaznosti na toto zjištění byl formulován názor, že by každý případ měl být hodnocen s přihlédnutím $\mathrm{k}$ tomu, zda zadavatel skutečně postupoval s cílem uzamčení vytvořit, či nikoli. Zadavatelé by neměli být trestáni za každé uzavření licenčních podmínek, které se v budoucnu ukáže jako nevýhodné. Právě takovýto přístup nutící zadavatele k vymezení zbytečně širokého (a většinou tedy i zbytečně nákladného) oprávnění by totiž ve svém důsledku přímo odporoval principu 3E.

V šesté kapitole je pozornost věnována uzamčení při migraci dat. Bylo upozorněno na povinné náležitosti smlouvy mezi správcem a zpracovatelem osobních údajů dle GDPR, které lze doporučit zařadit i do smluv o zpracování ostatních druhů dat. Právě kvalitně sestavená smlouva byla identifikována jako základní nástroj pro předejití uzamčení při migraci dat, nebot právní úprava mandatorní migrace není všeobjímající. V této části článku byla popsána i ona právní úprava mandatorní migrace dat dle nové zákonné úpravy. Tato úprava by mohla být inspirací i pro (adaptační) zákon o zpracování osobních údajů, který má být přijat v souvislosti s GDPR. Bylo tedy navrženo, aby mandatorní migrace byla upravena i v tomto zákoně. Zároveň byl vyjádřen názor, že by zákon o zpracování osobních údajů neměl snižovat pokuty stanovené GPDR, nebot je pravděpodobné, že snížení těchto pokut sníží i motivaci veřejných zadavatelů uzavírat s dodavateli řádné smlouvy o zpracování osobních údajů. Tyto smlouvy by přitom mohly snížit riziko uzamčení. Vedle toho byla nastíněna i teoretická možnost řešení vendor lock-inu za využití opatření k nápravě ze strany Úřadu pro ochranu osobních údajů.

Sedmá kapitola se věnovala uzamčení $\mathrm{z}$ důvodů vysokých nákladů na změnu. Byly popsány příčiny vzniku tohoto uzamčení, možnosti jeho předcházení i následného řešení (technologické změny směrem ke standardizovaným řešením, zahrnutí nových dodavatelů do parciálních projektů, insourcing a vedení dialogu se stávajícím dodavatelem). Dále byly uvedeny příklady tohoto lock-inu z českého právního prostředí, přičemž byl zvolen jak příklad exkluzivity zaviněné, tak nezaviněné. $V$ této části článku byly rovněž popsány př́ípady, kdy může důraz na hospodářskou soutěž, oproti 
využití JŘBU, vyústit ve zbytečně vynaložené náklady ze strany veřejného zadavatele.

V článku byla skrze výše uvedené koncipována východiska pro snížení počtu proprietárního uzamčení. Celý článek byl navíc doplněn o teoretické př́íklady i případy z praxe.

\section{POUŽITÉ ZDROJE}

\subsection{LITERATURA}

[1] AMARSY, Nabila. Switching Costs: 6 Ways To Lock Customers Into Your Ecosystem. Strategyzer.com [online]. Strategyzer.com, publikováno 27. 7. 2015 [cit. 4. 1. 2018]. Dostupné z: http://blog.strategyzer.com/posts/2015/7/27/switching-costs-6-strategies-to-lock-customersin-your-ecosystem

[2] ANDERSON, Birgitte. 'Intellectual Property Right' Or 'Intellectual Monopoly Privilege': Which One Should Patent Analysts Focus On? [online]. 2003, 32 s., [cit. 19. 9. 2017]. Dostupné z: http://citeseerx.ist.psu.edu/viewdoc/download?doi $=10.1 .1 .547 .3222 \&$ rep $=$ rep1\&type $=$ pdf

[3] ARROWSMITH, Sue. The Law of Public and Utilities Procurement. Vol. 1, ed. 3. London: Thomson Reuters, 2014, 1449 s. ISBN 978-0-421-96690-1.

[4] ASCHHOFF, Birgit; SOFKA, Wolfgang. Innovation on demand - Can public procurement drive market success of innovations? Research Policy. [Online]. 2009, vol. 8, issue 8, s. 12351247. [cit. 30. 11. 2017]. ISSN 0048-7333. Dostupné z: https://www.sciencedirect.com/science/article/pii/S0048733309001292

[5] BENTO, Alberto, AGGARWAL, Anil. Cloud Computing Service and Deployment Models. Hershey: Business Science Reference, 2013, 368 s. ISBN 978-1-4666-2188-6.

[6] BOROŠOVÁ, Hana, ŠEBESTA, Milan. Kvalifikace v otevřeném řízení dle návrhu zákona o zadávání veřejných zakázek. EPRAVO.CZ [online]. EPRAVO.CZ, a.s., publikováno 11. 12. 2015 [cit. 20. 11. 2017]. ISSN 1213-189X. Dostupné z: https://www.epravo.cz/top/clanky/kvalifikace-v-otevrenem-rizeni-dle-navrhu-zakona-ozadavani-verejnych-zakazek-99669.html

[7] BOZHANOV, Bozhidar. Bulgaria Got a Law Requiring Open Source. The Policy. [online] Medium, publikováno 4. 6. 2016 [cit. 4. 1. 2018]. Dostupné z: https://thepolicy.us/bulgariagot-a-law-requiring-open-source-98bf626cf70a

[8] BRÁZDIL, Martin. Rizika smluv o cloudových službách. PRÁVNÍ PROSTOR.CZ [online]. ATLAS consulting spol. s r.o., publikováno 28. 3. 2016 [cit. 6. 1. 2018]. ISSN 2336-4114. Dostupné z: https://www.pravniprostor.cz/clanky/ostatni-pravo/rizika-smluv-o-cloudovychsluzbach 
[9] CASTELLI, Annalisa. Technological lock-in and the shaping of enviromental policy. In: CASTELLUCCI, Laura (ed.). Government and the Environment: The Role of the Modern State in the Face of Global Challenges. London and New York: 2014, Routlege, s. 132-151. ISBN 978-0-41563354-3

[10] COCKCROFT. Adrian. Who Doesn't Like Lock-In? Battery.com. [online]. Battery Ventures, publikováno 20. 4. 2016 [cit. 24. 3. 2018]. Dostupné z: https://www.battery.com/powered/who-doesnt-like-lock-in/

[11] ČECH, Martin. Otázky zákonnosti postupu zadavatele při zadávání ICT veřejných zakázek v případě pořízení komplexního informačního systému v soutěži o návrh. EPRAVO.CZ [online]. EPRAVO.CZ, a.s., publikováno 4. 1. 2016 [cit. 4. 1. 2018]. ISSN 1213-189X. Dostupné z: https://www.epravo.cz/top/clanky/otazky-zakonnosti-postupu-zadavatele-prizadavani-ict-verejnych-zakazek-v-pripade-porizeni-komplexniho-informacniho-systemu-v-soutezi-o-navrh-99868.html

[12] DURAJ, Adam. Vendor lock-in in IT procurement [online]. Praha, 2017, 46 s. [cit. 25. 10. 2017]. Bakalářská práce. Karlova univerzita, Fakulta sociálních věd. Vedoucí práce Jiří SKUHROVEC. Dostupné z: https://is.cuni.cz/webapps/zzp/download/130206665/?lang = cs

[13] DVOŘÁK, David. Smluvní závazkové vztahy ve veřejných zakázkách [online]. Brno, 2013, 264 s. [cit. 19. 9. 2017]. Disertační práce. Masarykova univerzita, Právnická fakulta. Dostupné z: https://is.muni.cz/th/16692/pravf_d/Smluvni_zavazkove_vztahy_ve_verejnych_zakazkach _130913_final.pdf

[14] DVOŘÁK, David; MACHUREK, Tomáš; NOVOTNÝ Petr a kol. Zákon o zadávání veřejných zakázek. Komentár̆. Praha: Nakladatelství C. H. Beck, 2017, 1320 s. ISBN 978-80-7400-651-7.

[15] EBBESSON, Bjöm; OISSON, Thomas. Managing divergences in IT infrastructure standardization [online]. Göteborg, 2018, 48 s. [cit. 1. 11. 2017]. Master thesis in IT management. IT University of Göteborg, Chalmers University of Technology and University of Gothenburg. Dostupné z: https://gupea.ub.gu.se/bitstream/2077/10453/1/gupea_2077_10453_1.pdf

[16] FARRELL, Joseph; KLEMPERER, Paul. Coordination and lock-in: competition with swithing costs and network effect. In: ARMSTRONG, M.; PORTER, R. (eds.). Handbook of Industrial Organization. [Online]. 2007, vol. 3, s. 1970-2071. [cit. 30. 11. 2017]. Dostupné z: http://www.nuff.ox.ac.uk/users/klemperer/Farrell_KlempererWP.pdf

[17] FRANCOVÁ, Anna. Kritéria hodnocení nabídek ve veřejných zakázkách. PRÁVNÍ PROSTOR.CZ [online]. ATLAS consulting spol. s r.o., publikováno 9. 3. 2017 [cit. 7. 1. 2018]. ISSN 2336-4114. Dostupné z: https://www.pravniprostor.cz/clanky/spravni-pravo/kriteriahodnoceni-nabidek-ve-verejnych-zakazkach

[18] FRIČOVÁ, Vítezslava. Shrnutí judikatury k problematice zadávání veřejných zakázek v oblasti IT v jednacím řízení bez uveřejnění. Zakázkové právo $v$ oblasti ICT a další aktuální témata - Informační list [online]. 2017, č. 1, s. 34 [cit. 4. 1. 2018]. Dostupné z: http://www.uohs.cz/download/Informacni_listy/2017/2017_1_Zakazkove-pravo-a-oblasti-ICT.PDF 
[19] GHOSH, Rishab. An Economic Basis for Open Standards. In: DeNaris, Laura (ed.). Opening Standards: The Global Politics of Interoperability. Cambdridge, Massachusetts: The MIT Press, 2011, s. 75 - 97. ISBN 978-0-262-01602-5.

[20] GLADER, Marcus. Open standards: Public Policy aspects and competition law requirements. European Competition Journal [Online]. 2010, vol. 6, no. 1, s. 611-648. [cit. 28. 11. 2017]. Dostupné z: http://heinonline.org/HOL/P?h = hein.journals/jleo11\&i $=211$

[21] HARSH, Piyush, DUDOUET, Florian, CASCELLA, Roberto a kol. Using Open Standards for Interoperability - Issues, Solutions, and Challenges facing Cloud Computing [online]. 2012, 6 s. [cit. 6. 11. 2017]. Dostupné z: https://arxiv.org/pdf/1207.5949.pdf

[22] HERMAN, Pavel; FIDLER, Vlastimil; ADÁMKOVÁ, Markéta a kol. Komentár k zákonu o zadávání veřejných zakázek. 2. vyd. Plzeň: Aleš Čeněk, 2016, s. 639 s. ISBN 978-80-7380-6606.

[23] HORKÝ, Michal. Možnosti efektivního zadávání veřejných zakázek z hlediska právní regulace $v$ České republice [online]. Praha, 2017, 94 s. [cit. 21. 3. 2018]. Diplomová práce. Univerzita Karlova, Právnická fakulta. Vedoucí práce Radim BOHÁč. Dostupné z: https://dspace.cuni.cz/bitstream/handle/20.500.11956/92323/DPTX_2015_2_11220_0_35375 1_0_177028.pdf?sequence $=1$

[24] CHAN, Mike. 6 things you can do to avoid cloud vendor lock-in. ThornTech.com [online]. Thorn Technologies LLC, publikováno 18. 9. 2017 [cit. 6. 1. 2018]. Dostupné z: https://www.thorntech.com/2017/09/avoidingcloudvendorlockin/

[25] CHÝLE, Josef. Jaké otázky si klást v IT veřejných zakázkách před zahájením migrace dat a problematika vendor lock-in. Zakázkové právo v oblasti ICT a dalš́ aktuální témata - Informační list [online]. 2017, č. 1, s. 19 - 25 [cit. 4. 1. 2018]. Dostupné z: http://www.uohs.cz/download/Informacni_listy/2017/2017_1_Zakazkove-pravo-a-oblastiICT.PDF

[26] KMOCH, Ondřej. IT veřejné zakázky - co zvažovat při aplikaci postoupení oprávnění $\mathrm{k}$ výkonu majetkových práv autorských a dílčí zamyšlení na závěr. EPRAVO.CZ [online]. EPRAVO.CZ, a.s., publikováno 29. 1. 2016 [cit. 1. 11. 2017]. ISSN 1213-189X. Dostupné z: https://www.epravo.cz/top/clanky/it-verejne-zakazky-co-zvazovat-pri-aplikaci-postoupeniopravneni-k-vykonu-majetkovych-prav-autorskych-a-dilci-zamysleni-na-zaver-99539.html

[27] LIEBOWITZ, Stan; MARGOLIS, Stephen. Path Dependence, Lock-In, and History. Journal of Law, Economics and Organization [Online]. 1995, vol. 11, no. 1, s. 205-226. [cit. 1. 10. 2017]. Dostupné z: http://heinonline.org/HOL/P?h $=$ hein.journals/jleo11\&i $=211$

[28] LIEBOWITZ, Stan; MARGOLIS, Stephen: Network Externality: An Uncommon Tragedy. The New Palgrave's Dictionary of Economics and the Law [online]. 1998, vol. 8, no. 2, s. 133-150 [cit. 30. 11. 2017]. Dostupné z: http://www.jstor.org/stable/2138540

[29] MOON, Mariella. NYPD starts replacing cops' Windows Phones with iPhones. Engadget.cz [online]. Oath Tech Network Aol Tech., publikováno 6. 2. 2018 [cit. 6. 2. 2018]. Dostupné z: https://www.engadget.com/2018/02/06/nypd-starts-replacing-cops-windows-phones-withiphones/ 
[30] NEJEZCHLEB, Kamil; HAJNÁ, Zuzana. Stanovení tržní síly a její význam v soutěžním právu. Časopis pro právní vědu a praxi. [Online]. 2013, č. 4, s. 515-524. [cit. 21. 3. 2018]. ISSN 1805-2789. Dostupné z: https://journals.muni.cz/cpvp/article/view/5668

[31] NULÍČEK, Michal; DONÁT, Josef; NONNEMANN František a kol. Obecné nařizení o ochraně osobních údajů (GDPR): Praktický komentář. In: ASPI [právní informační systém]. Wolters Kluwer [cit. 22. 3. 2018]. ISSN 2336-517X.

[32] OPARA-MARTINS, Justice; SAHANDI, Reza; TIAN, Feng. Critical analysis of vendor lockin and its impact on cloud computing migration: a business perspective. Journal of Cloud Computing [Online]. 2016 [cit. 4. 1. 2018]. Dostupné z: https://doi.org/10.1186/s13677-0160054-z

[33] PODEŠVA, Vilém; SOMMER, Lukáš; VOTRUBEC, Jiří a kol. Zákon o zadávání veřejných zakázek. Komentár̆. Praha: Wolters Kluver (ČR), 2017, 1079 s. ISBN 978-80-7552-102-6.

[34] POLČÁK, Radim. Informace a data v právu. Revue pro právo a technologie [Online]. 2016, č. 13, s. 67-91. [cit. 8. 1. 2018]. ISSN 1805-2797. Dostupné z: https://journals.muni.cz/revue/article/view/4946

[35] POREMSKÁ, Michaela. ICT in Public Procurement Can Lead to Cybercrimes?. Masaryk University Journal of Law and Technology [Online]. 2014, vol. 4, no. 2, s. 157-171. [cit. 26. 10. 2017]. ISSN 1802-5951. Dostupné z: https://journals.muni.cz/mujlt/article/view/2565/2129

[36] RAFAJ, Petr; FRIČOVÁ, Vítězslava. Vybrané instituty práva veřejných zakázek v judikatư̌e Soudního dvora EU a jejich úprava v nových zadávacích směrnicích. Bulletin advokacie. 2015, č. 9, s. 39-44. ISSN 1210-6348.

[37] SEROTER, Richard. Everything Is "Lock-In": Focus on Switching Costs. InfoQ.com [online]. C4Media Inc., publikováno: 8. 6. 2016 [cit. 25. 10. 2017]. Dostupné z: https://www.infoq.com/articles/avoiding-lockin-switching-costs

[38] SHAH, Rajiv; KESAN, Jay; KENNIS, Andrew. Lessons for Open Standard Policies: A Case Study of the Massachusetts Experience. International Conference on Theory and Practice of Electronic Governance, Illinois Public Law Research Paper No. 0713. [online] University of Illinois, 2007, 12 s. [cit. 1. 10. 2017]. Dostupné z: https://papers.ssrn.com/sol3/papers.cfm?abstract_id $=1028133$

[39] SHARPE, Nicola; AREWA, Olufunmilayo. Is Apple Playing Fair? Navigating the iPod FairPlay DRM Controversy. Northwestern Journal of Technology and Intellectual Property. [online]. 2007, vol. 5 s. 332-350 [cit. 21. 10. 2017]. Dostupné z: http://scholarlycommons.law.northwestern.edu/njtip/vol5/iss2/5

[40] SCHMIDT, Martin. Pokuty za správní delikty ve veřejných zakázkách: ekonometrický model. Acta Oeconomica Pragensia [online]. 2014, vol. 6, s. 35-50 [cit. 30. 11. 2017]. Dostupné z: https://doi.org/10.18267/j.aop.457

[41] SCHULTE, Benjamin Krischan. Staying the Consumption Course: Exploring the Individual Lock-in Process in Service Relationships. Berlin: Springer Fachmedien Wiesbaden, 2015, 240 s. ISBN 9783658087876. 
[42] SJOERDSTRA, Bianca. Dealing with Vendor Lock-in [online]. Enschede, 2016, s. 14 [cit. 19. 9. 2017]. University of Twente, The Faculty of Behavioural, Management and Social sciences. Dostupné z: http://essay.utwente.nl/70153/1/Sjoerdstra_BA_BMS.pdf

[43] SKUHROVEC, Jiří. Vendor lock-in ve veřejných zakázkách [online]. Publikováno 16. 6. 2013, 20 s. [cit. 19. 9. 2017]. Dostupné z: https://www.nku.cz/assets/konferenceseminare/2013/konference-vz-2013/11_Skuhrovec_CAE.pdf

[44] SOCHOR, Miloš. Právní aspekty ochrany osobních údajů v rámci cloudových služeb. PRÁVNÍ PROSTOR.CZ [online]. ATLAS consulting spol. s r.o., publikováno 27. 2. 2017 [cit. 10. 1. 2018]. ISSN 2336-4114. Dostupné z: https://www.pravniprostor.cz/clanky/obcanskepravo/pravni-aspekty-ochrany-osobnich-udaju-v-ramci-cloudovych-sluzeb

[45] SUTOR, Robert. Software Standards, Openness, and Iteroperability. In: DeNaris, Laura (ed.). Opening Standards: The Global Politics of Interoperability. Cambdridge, Massachusetts: The MIT Press, 2011, s. 209-218. ISBN 978-0-262-01602-5.

[46] SVOBODA, Jan. Veřejné zakázky v oblasti ICT a problém závislosti zadavatele na dodavateli. Brno, 2018, 64 s. Diplomová práce. Masarykova Univerzita, Právnická fakulta. Vedoucí práce Radim POLČÁK.

[47] ŠIMKOVÁ, Dana. Přehled právní úpravy veřejného zadávání na úrovni EU a ve vybraných členských státech [online]. 2014, s. 43, Studie č. 5.344 [cit. 19. 9. 2017]. Poslanecká sněmovna Parlamentu České republiky. Dostupné z: www.psp.cz/sqw/text/orig2.sqw?idd $=97312$

[48] TER, Kah Leng. Path Dependence, Lock-in and Lock-out Agreements. Singapore Academy of Law Journal [Online]. 1992, vol. 4, s. 349-358. [cit. 26. 10. 2017]. ISSN 0218-2009. Dostupné z: http://heinonline.org/HOL/P?h = hein.journals/saclj4\&i $=361$

[49] TRIDLA, Radek. Potenciál a limity využití open source ve veřejné správě [online]. Brno, 2012, 64 s. [cit. 1. 11. 2017]. Bakalářská práce. Masarykova univerzita, Ekonomicko-správní fakulta. Vedoucí práce David ŠPAČEK. Dostupné z: https://is.muni.cz/th/323191/esf_b/BP_Radek_Trlida.pdf

[50] USURO, Abel. Research in Information Systems. In: ATKINSON, John; CROWE; Malcom (eds.). Interdisciplinary Research: Diverse Approaches in Science, Technology, Health and Society. Chichester: 2006, John Wiley \& Sons Ltd, s. 75-100. ISBN-13: 978-1-86156-470-2.

[51] VARIAN, Hal R.; FARRELL, Joseph; SHAPIRO, Carl. The Economics of Information Technology: An Introduction. New York: Cambridge University Press, 2004, 114 s. ISBN 9780521844154.

[52] VÉVODA, Petr. Data obsažená v IT systémech, jejich vlastnictví a zakázkové právo. Zakázkové právo v oblasti ICT a další aktuální témata - Informační list [online]. 2017, č. 1, s. 15 - 18 [cit. 1.018 2018]. http://www.uohs.cz/download/Informacni_listy/2017/2017_1_Zakazkove-pravo-a-oblastiICT.PDF 
[53] WEST, Joel. The Economic Realities of Open Standards: Black, White and Many Shades of Gray. In: GREENSTEIN, Shane; STANGO; Victor (eds.). Standards and Public Policy [Online]. Cambdridge: Cambridge University Press, 2005, 38 s. [cit. 21. 3. 2018]. Dostupné z: https://pdfs.semanticscholar.org/0a79/8fe04998710ab69957eb1dbabfd83fe91866.pdf

\subsection{ROZHODOVACÍ PRAXE SPRÁVNÍCH ORGÁNU゚ A JUDIKATURA}

[54] Př́íkaz Úřadu pro ochranu osobních údajů ze dne 17. 10. 2017, č. j. UOOU-09611/17-8. Úřad pro ochranu osobních údajů [online]. Úřad pro ochranu osobních údajů, 2016 [cit. 28. 3. 2018]. Dostupné z: https://www.uoou.cz/assets/File.ashx? id_org $=200144 \&$ id_dokumenty $=28251$

[55] Př́íkaz Úřadu pro ochranu osobních údajů ze dne 21. září 2016, č. j. UOOU-08449/16-3. Úřad pro ochranu osobních údajů [online]. Úřad pro ochranu osobních údajů, 2016 [cit. 28. 3. 2018]. Dostupné z: https://www.uoou.cz/assets/File.ashx? id_org $=$ 200144\&id_dokumenty $=21411$

[56] Rozhodnutí předsedy Úřadu pro ochranu hospodářské soutěže o rozkladu ze dne 2. 1 . 2018, č. j. ÚOHS-R0192/2017/VZ-37799/2017/323/Lva. In: ASPI [právní informační systém]. Wolters Kluwer ČR [cit. 24. 3. 2018].

[57] Rozhodnutí Úřadu pro ochranu hospodářské soutěže ze dne 11. 10. 2017, č. j. ÚOHSS0309/2017/VZ-29605/2017/523/HVo. In: ASPI [právní informační systém]. Wolters Kluwer ČR [cit. 24. 3. 2018].

[58] Rozhodnutí Úřadu pro ochranu hospodářské soutěže ze dne 12. 4. 2012, č. j. ÚOHSS364/2011/VZ-4144/2012/540/PVé. In: ASPI [právní informační systém]. Wolters Kluwer ČR [cit. 24. 3. 2018].

[59] Rozhodnutí Úřadu pro ochranu hospodářské soutěže ze dne 13. 11. 2014, č. j. S751/2014/VZ-24208/2014/542/JVO. In: ASPI [právní informační systém]. Wolters Kluwer ČR [cit. 24. 3. 2018].

[60] Rozhodnutí Úřadu pro ochranu hospodářské soutěže ze dne 15. 10. 2009, č. j. ÚOHSS109/2009/VZ12164/2009/510/Hod. In: ASPI [právní informační systém]. Wolters Kluwer ČR [Cit. 24. 3. 2018].

[61] Rozhodnutí Úřadu pro ochranu hospodářské soutěže ze dne 18. 4. 2011, č. j. ÚOHSS448/2010/VZ-3396/2011/540/VKu. In: ASPI [právní informační systém]. Wolters Kluwer ČR [cit. 24. 3. 2018].

[62] Rozhodnutí úřadu pro ochranu hospodářské soutěže ze dne 22. 5. 2014, č. j. ÚOHSS140/2014/VZ-10908/2014/531/Olu/LFr. In: ASPI [právní informační systém]. Wolters Kluwer ČR [cit. 24. 3. 2018].

[63] Rozhodnutí Úřadu pro ochranu hospodářské soutěže ze dne 23. 5. 2014, č. j. ÚOHSS604/2013/VZ-10977/2014/522/PLy. In: ASPI [právní informační systém]. Wolters Kluwer ČR [cit. 24. 3. 2018]. 
[64] Rozhodnutí Úřadu pro ochranu hospodářské soutěže ze dne 29. 6. 2017, č. j. ÚOHSS0186/2017/VZ-19607/2017/553/MBU. In: ASPI [právní informační systém]. Wolters Kluwer ČR [cit. 24. 3. 2018].

[65] Rozhodnutí úřadu pro ochranu hospodářské soutěže ze dne 30. 8. 2017, č. j. ÚOHSS0277/2017/VZ-25377/2017/532/KSt. In: ASPI [právní informační systém]. Wolters Kluwer ČR [cit. 24. 3. 2018].

[66] Rozhodnutí Úřadu pro ochranu hospodářské soutěže ze dne 9. 6. 2014, č. j. ÚOHSS108/2009/VZ-12162/2014/521/VSt. In: ASPI [právní informační systém]. Wolters Kluwer ČR [cit. 24. 3. 2018].

[67] Rozhodnutí Úřadu pro ochranu osobních údajů ze dne 16. 11. 2017, č. j. UOOU-08211/17-13. Úřad pro ochranu osobních údajů [online]. Úřad pro ochranu osobních údajů, (C) 2016 [cit. 28. 3. 2018]. Dostupné z: https://www.uoou.cz/assets/File.ashx? id_org $=200144 \&$ id_dokumenty $=28250$

[68] Rozsudek Krajského soudu v Brně ze dne 26. 4. 2012, č. j. 62 Af 61/2010 - 332. In: ASPI [právní informační systém]. Wolters Kluwer ČR [cit. 24. 3. 2018].

[69] Rozsudek Nejvyššího správní soudu ze dne 12. 5. 2016, č. j. 1 As 256/2015 - 95. In: ASPI [právní informační systém]. Wolters Kluwer ČR [cit. 24. 3. 2018].

[70] Rozsudek Nejvyššího správního soudu ze dne 11. 1. 2013, č. j. 5 Afs 42/2012 - 53. In: ASPI [právní informační systém]. Wolters Kluwer ČR [cit. 24. 3. 2018].

[71] Rozsudek Nejvyššího správního soudu ze dne 5. 6. 2008, č. j. 1 Afs 20/2008 - 152. In: ASPI [právní informační systém]. Wolters Kluwer ČR [cit. 24. 3. 2018].

[72] Rozsudek soudního dvora ze dne 14. 9. 2004, věc C-385/02, Komise Evropských společenství proti Italské republice [online]. InfoCuria - Judikatura Soudního dvora [cit. 5. 3. 2018]. Dostupné z: http://eur-lex.europa.eu/legal-content/CS/ALL/uri=CELEX:62002CJ0385

[73] Rozsudek Vrchního soudu v Olomouci ze dne 5. 11. 2002, č. j. 2 A 3/2002-75. In: ASPI [právní informační systém]. Wolters Kluwer ČR [cit. 24. 3. 2018].

\subsection{PRÁVNÍ PŘEDPISY}

\subsubsection{ZÁKONY}

[74] Zákon č. 121/2000 Sb., autorský zákon, ve znění pozdějších předpisů. In: ASPI [právní informační systém]. Wolters Kluwer ČR [cit. 24. 3. 2018].

[75] Zákon č. 134/2016 Sb., zákon o zadávání veřejných zakázek, ve znění pozdějších předpisů. In: ASPI [právní informační systém]. Wolters Kluwer ČR [cit. 24. 3. 2018].

[76] Zákon č. 137/2006 Sb., zákon o veřejných zakázkách, ve znění pozdějších přepsisů. In: ASPI [právní informační systém]. Wolters Kluwer ČR [cit. 24. 3. 2018].

[77] Zákon č. 143/2001 Sb., o ochraně hospodářské soutěže, ve znění pozdějších předpisů. In: ASPI [právní informační systém]. Wolters Kluwer ČR [cit. 24. 3. 2018]. 
[78] Zákon č. 181/2014 Sb., o kybernetické bezpečnosti, ve znění pozdějších předpisů. In: ASPI [právní informační systém]. Wolters Kluwer ČR [cit. 24. 3. 2018].

[79] Zákon č. 365/2000 Sb., o informačních systémech veřejné správy, ve znění pozdějších předpisů. In: ASPI [právní informační systém]. Wolters Kluwer ČR [cit. 24. 3. 2018].

\subsubsection{PRÁVNÍ PŘEDPISY EU}

[80] Nařízení Evropského parlamentu a Rady (EU) č. 2016/679 ze dne 27. 4. 2016 o ochraně fyzických osob v souvislosti se zpracováním osobních údajů a o volném pohybu těchto údajů a o zrušení směrnice 95/46/ES. In: ASPI [právní informační systém]. Wolters Kluwer ČR [cit. 24. 3. 2018].

[81] Nařízení Rady (ES) č. 1/2003 ze dne 16. 12. 2002 o provádění pravidel hospodářské soutěže stanovených v článcích 81 a 82. In: ASPI [právní informační systém]. Wolters Kluwer ČR [cit. 24. 3. 2018].

[82] Směrnice Evropského parlamentu a Rady č. 2014/24/EU ze dne 26. 2. 2014 o zadávání veřejných zakázek a o zrušení směrnice 2004/18/ES. In: ASPI [právní informační systém]. Wolters Kluwer ČR [cit. 24. 3. 2018].

[83] Směrnice Evropského parlamentu a Rady 2014/25/EU ze dne 26. 2. 2014 o zadávání zakázek subjekty působícími v odvětví vodního hospodářství, energetiky, dopravy a poštovních služeb a o zrušení směrnice 2004/17/ES. In: ASPI [právní informační systém]. Wolters Kluwer ČR [cit. 24. 3. 2018].

[84] Směrnice Evropského parlamentu a Rady 2009/81/ES ze dne 13. 7. 2009 o koordinaci postupů při zadávání některých zakázek na stavební práce, dodávky a služby zadavateli v oblasti obrany a bezpečnosti a o změně směrnic 2004/17/ES a 2004/18/ES. In: ASPI [právní informační systém]. Wolters Kluwer ČR [cit. 24. 3. 2018].

\subsection{DALŠÍ ZDROJE}

[85] Cloud Data Management Interface (CDMI) [online]. SIA [cit. 6. 1. 2018]. Dostupné z: https://www.snia.org/cdmi

[86] Důvodová zpráva k zákonu č. 134/2016 Sb. o zadávání veřejných zakázek. In: Beck-online [online právní informační systém]. Nakladatelství C. H. Beck [cit. 22. 3. 2018]. Dostupné z: https://www.beck-online.cz/bo/chapterview-document.seam?documentId = oz5f6mrqge3f6mjtgrpwi6q\#

[87] Důvodová zpráva k zákonu č. 104/2017 Sb. In: Beck-online [online právní informační systém]. Nakladatelství C. H. Beck [cit. 22. 3. 2018]. Dostupné z: https://www.beckonline.cz/bo/chapterview-document.seam?documentId = oz5f6mrqge3v6mjqgrpwi6q

[88] Důvodová zpráva k zákonu č. 181/2014 Sb. o kybernetické bezpečnosti a o změně souvisejících zákonů. In: Beck-online [online právní informační systém]. Nakladatelství C. H. Beck [cit. 22. 3. 2018]. Dostupné z: https://www.beck-online.cz/bo/chapterview-document.seam? documentId = oz5f6mrqge2f6mjygfpwi6q\# 
[89] GORDIC Partner Program [online]. GORDIC spol. s.r.o. [cit. 26. 3. 2018]. Dostupné z: https://www.gordic.cz/profil-spolecnosti/gordic-partner-program/

[90] Metodický pokyn CHJ č. 3. - Metodika veřejného nakupování: Naplňování principu 3E v praxi veřejného zadávání [online]. Publikováno 7. 7. 2016 [cit. 6. 11. 2017]. Dostupné z: http://www.mfcr.cz/assets/cs/media/Metodika_2016_Metodicky-pokyn-CHJ-c-3.pdf

[91] Nevýhodná ujednání ve smlouvách na dodávku ICT produkti̊ [online]. Odbor Hlavního architekta eGovernmentu Ministerstva vnitra, 2017, 3 s. [cit. 25. 12. 2018]. Dostupné z: https://1url.cz/LMHgk

[92] O-DEF [online]. The Open Group [cit. 6. 1. 2018]. Dostupné z: http://www.opengroup.org/subjectareas/platform3.0/o-def

[93] Oznámení o zadání zakázky [online]. Věstník veřejných zakázek, uveřejněno 2. 3. 2016, ev. č. zakázky 516680 [cit. 22. 3. 2018]. Dostupné z:

https://old.vestnikverejnychzakazek.cz/en/Form/Display/647460

[94] Pre-Commercial Procurement [online]. European Commission [cit. 26. 3. 2018]. Dostupné z: https://ec.europa.eu/digital-single-market/en/pre-commercial-procurement

[95] Sněmovní tisk 138 (8. volební období), návrh zákona o zpracování osobních údajů [online]. Úřad vlády České republiky [cit. 28. 3. 2018]. Dostupné z: https://apps.odok.cz/veklepdetail?pid= KORNAQCDZPW5

[96] Study on best practices for ICT procurement based on standards in order to promote efficiency and reduce lock-in [online]. 2015, 22 s. [cit. 1. 10. 2017]. Dostupné z: https://joinup.ec.europa.eu/sites/default/files/inline-files/Task_4_Survey_results'_analysis.pdf

[97] Opinion 05/2012. Article 29 Data Protection Working Party [online]. Přijato 1. 7. 2012, 27 s. [cit. 26. 12. 2018]. Dostupné z: https://ec.europa.eu/justice/article29/documentation/opinion-recommendation/files/2012/wp196_en.pdf

Toto dílo lze užít v souladu s licenčními podmínkami Creative Commons BY-SA 4.0 International (http://creativecommons.org/licenses/by-sa/4.0/legalcode). 